STUDIA POLONIJNE

T. 42 LUBLIN 2021

DOI: http://doi.org/10.18290/sp2 142.23

JÓZEF WOŁCZAŃSKI

\author{
LISTY KS. WINCENTEGO DANKA \\ DO ABP. JÓZEFA BILCZEWSKIEGO Z LAT 1900-1919 \\ (CZĘŚĆ I)
}

\begin{abstract}
WSTĘP
Jednym z wielce zasłużonych duchownych archidiecezji lwowskiej ob. łac. na polu duszpasterstwa polonijnego na obczyźnie był ks. Wincenty Eugeniusz Danek (1870-1945). Jego biografia obfituje w liczne „białe plamy”, a mimo niezwykłych życiowych osiągnięć nie doczekał się dotąd pogłębionej biografii. Badacze napotykają bowiem na przeszkody w dotarciu do źródeł bądź ich eksploracji, a dotychczas funkcjonujące ustalenia w odniesieniu do curriculum vitae owego duchownego są w dużej mierze błędne. W niniejszym opracowaniu po raz pierwszy wykorzystano do rekonstrukcji jego drogi życiowej nieznane dotąd źródła archiwalne.

Wincenty Eugeniusz Danek przyszedł na świat 14 XI 1870 r. w Stryju w rodzinie inteligenckiej ${ }^{1}$. Jego ojcem był Leopold Stanisław Emilian (1841-1906), syn Wincentego (1812-1879) i Florentyny Macielińskiej (1818-1886)2,
\end{abstract}

Ks. prof. dr hab. JózeF WoŁCZAŃSKI - Wydział Historii i Dziedzictwa Kulturowego Uniwersytetu Papieskiego Jana Pawła II w Krakowie; e-mail: jwolczan@wp.pl; ORCID: https:// orcid.org/0000-0001-6210-1411.

${ }^{1}$ Błędną informację odnośnie do miejsca i miesiąca urodzenia podaje ks. Maciej Józefowicz w artykule z 1996 r., wskazując na Kuty (Huculszczyzna) i wrzesień 1870 r., ale w późniejszej pracy z 2005 r. koryguje te dane. Błędną hipotezą jest również stwierdzenie tegoż autora dotyczące rzekomego ziemiańskiego pochodzenia ks. Danka. M. Józefowicz, Kościót polski w Budapeszcie „małym Rapperswil”, „Archiwa, Biblioteki i Muzea Kościelne” 1996, t. 65, s. 427; TENŻE, Ks. kan. Wincenty Danek - polski święty Jan Vianney, „Zeszyty Historyczne PSK im. Józefa Bema na Węgrzech" 2005, z. 2, s. 9.

${ }^{2}$ Florentyna Danek zmarła 4 XI 1886 r. we Lwowie na terenie parafii pw. św. Andrzeja Apostoła (oo. Bernardynów), co pozwala ustalić rejon zamieszkania wraz z mężem - ścisłe Stare Miasto. Archiwum Główne Akt Dawnych w Warszawie, sygn. 783, Księga zmarłych parafii św. Andrzeja we Lwowie 1886-1892, s. 112. 
urodzony w Mościskach k. Przemyśla³ . Matką zaś Maria Burkhart/Burkhardt (?-1880), córka Antoniego i Pauliny Szenk ${ }^{4}$. Dziadek Wincenty Danek należał do elity urzędniczej i artystycznej Lwowa. Z wykształcenia prawnik, doszedł do stanowiska nadprokuratora i radcy dworu. W stolicy Galicji cieszył się zasłużoną sławą miłośnika i znawcy muzyki, skomponował 16 polonezów oraz opublikował ponad 50 zeszytów, m.in. popularnych tańców na fortepian. Pełnił też w latach 1871-1877 funkcję prezesa Galicyjskiego Towarzystwa Muzycznego. Po śmierci pochowany został na Cmentarzu Łyczakowskim we Lwowie ${ }^{5}$.

W ślady ojca poszedł syn Stanisław Leopold Emilian, wybierając karierę prawniczą. Po ukończeniu studiów zapewne na Uniwersytecie Lwowskim objął w 1866 r. posadę auskultanta w Sądzie Krajowym we Lwowie ${ }^{6}$. W 1868 r. źródła rejestrują jego nazwisko na analogicznym stanowisku w Sądzie Rejonowym w Brodach ${ }^{7}$. W latach 1869-1876 pełnił obowiązki adiunkta Sądu Powiatowego w Stryju ${ }^{8}$. Tam małżeństwu Danków narodziło się trzech synów i jedna córka: Władysław - 28 IV 1869 r., Wincenty - 14 XI 1870 r. (przyszły duchowny), Maria Wanda - 31 I 1872 r. $^{9}$ i Stanisław - 26 III 1873 r. $^{10}$ Po kilku latach pobytu w Stryju, w 1877 r. rodzina przeniosła się ze względu na obowiązki służbowe Stanisława do Kołomyi, gdzie kontynuował on pracę

${ }^{3} \mathrm{~W}$ późniejszych dokumentach funkcjonował jako Stanisław Leopold Danek lub Stanisław Danek. Archiwum Archidiecezji Przemyskiej, bsygn., Akta metrykalne parafii Mościska, Extractus Copulatorum, Natorum, Sepultorum Parochiae Mosciscensis r. 1., Liber Baptizatorum Parochia Mościska 1841, s. 5.

${ }^{4}$ Przytoczoną tu formę nazwiska panieńskiego Marii podają księgi parafialne parafii Kuty i Zabłotów. Inną formę: Brückhard, ale bez wskazania źródła, przytacza w swej publikacji Gabriel Szuster. Archiwum Archidiecezji Lwowskiej ob. łac. w Krakowie [dalej: AALK], sygn. CXIV-5, Metrykalia. Parafia Kuty, Liber bannorum 1875-1945, k. 19; AALK, sygn. CCLX-6, Metrykalia. Книга народжень в Заболотові 1867-1888 p., t. 4, s. 91; G. SZUSTER, Wincenty Danek (1907-1976). Biografia nauczyciela, Kraków 2017, s. 23.

5 J.J. Dunicz, Danek Wincenty, [w:] Polski Stownik Biograficzny, t. IV, red. W. Konopczyński, Kraków 1938, s. 402-403; J. HabEla, Danek Wincenty, [w:] Encyklopedia muzyczna PWM, t. II, red. E. Dziębowska, Kraków 1984, s. 337; S.S. NicIEJA, Lyczaków. Dzielnica za Styksem, Wrocław-Warszawa-Kraków 1998, s. 426.

${ }^{6}$ Handbuch des Statthalterei-Gebietes in Galizien für das Jahr 1866, Lemberg 1866, s. 129.

${ }^{7}$ Galizisches Provinzial-Handbuch für das Jahr 1868, Lemberg 1868, s. 227.

${ }^{8}$ Galizisches Provinzial-Handbuch für das Jahr 1869, Lemberg 1869, s. 120; Szematyzm królestwa Galicji i Lodomerii z wielkim księstwem krakowskim na rok 1870-1876, Lwów 18701876, passim.

${ }^{9}$ Maria Wanda w wieku 18 lat poślubiła 27 IV 1890 r. w Kutach Ormianina, właściciela dóbr Baniłów na Bukowinie, Bogdana Bohosiewicza. AALK, sygn. CXIV-5, Metrykalia. Parafia Kuty, Liber bannorum 1875-1945, k. 45.

${ }^{10}$ AALK, sygn. CCXVIII-1, Metrykalia. Parafia Stryj, Index natorum 1807-1873, k. 30; AALK, sygn. CXIV-7, Metrykalia. Kuty, Status animarum 1901-1945. 
na tym samym stanowisku co dotychczas w Sądzie Obwodowym ${ }^{11}$. Rok później cała rodzina osiadła w Zabłotowie, gdzie Stanisław awansował na stanowisko sędziego Sądu Powiatowego - Okrąg Sądowy w Kołomyi ${ }^{12}$. Tam 11 XI 1878 r. przyszło na świat dwóch kolejnych synów-bliźniaków Stanisława i Marii Danków: Michał i Kazimierz ${ }^{13}$. Wreszcie w 1881 r. Dankowie trafili do Kut na Huculszczyznę, gdzie nestor rodziny do 1887 r. pełnił obowiązki sędziego Sądu Powiatowego - Okrąg Kołomyja ${ }^{14}$. Dwa lata później, po osiedleniu się rodziny w Kutach, 9 VI 1880 r. zmarła jego żona ${ }^{15}$. Owdowiały 39-letni sędzia po upływie dwóch lat, 6 I 1882 r., zawarł tamże drugie małżeństwo z Marcelą Bostan (1844-?), córką Waleriana i Anny $\mathrm{z}$ d. Krzysztofowicz, obrządku ormiańskokatolickiego, urodzoną w Żabiu, a zamieszkałą wówczas w Kutach ${ }^{16}$. Nie zdołano ustalić żadnych danych na temat potomstwa tejże pary; prawdopodobnie nie doczekano się go. Aktywność zawodową w sferze sądownictwa Stanisław Danek zakończył w 1888 r., przechodząc na emeryturę z poborami 500 złr rocznie ${ }^{17}$.

W rodzinie Danków pielęgnowano tradycje prawnicze; jak już wcześniej wspomniano, ojciec Stanisława - Wincenty pełnił obowiązki nadprokuratora we Lwowie. W jego ślady poszedł Stanisław. Jak się później okazało, również drugi syn Stanisława - Wincenty, jako pierwszy kierunek studiów wybrał prawo. Z powodu braku źródeł nie sposób zrekonstruować lat szkolnych Wincentego. Zapewne edukację rozpoczął w Stryju, po czym kontynuował ją w Kutach. Potwierdzone źródłowo informacje dotyczą dopiero okresu studiów uniwersyteckich. Otóż przypisuje mu się ukończenie studiów na Wydziale Prawa i Umiejętności Politycznych Uniwersytetu Lwowskiego, ale

${ }^{11}$ Szematyzm królestwa Galicji i Lodomerii z wielkim księstwem krakowskim na rok 1877, Lwów 1877, s. 88.

${ }^{12}$ Szematyzm królestwa Galicji i Lodomerii z wielkim księstwem krakowskim na rok 1878-1880, Lwów 1878-1880, passim.

${ }^{13}$ Niemowlęta narodziły się z jakimś defektem, bowiem Kazimierz zmarł po miesiącu 20 XII 1878 r., zaś Michała oddano do zamkniętego zakładu opiekuńczego we Lwowie, gdzie zmarł w wieku 12 lat 3 IV 1890 r. AALK, sygn. CCLX-6, Metrykalia. Книга народжень в Заболотові 1867-1888 p., t. 4, s. 91.

${ }^{14}$ Szematyzm królestwa Galicji i Lodomerii z wielkim księstwem krakowskim na rok 1881-1887, Lwów 1881-1887, passim.

${ }^{15}$ AALK, bsygn., Metrykalia. Parafia Kuty, Index mortuorum 1780-1945.

${ }^{16}$ AALK, sygn. CXIV-5, Metrykalia. Parafia Kuty, Liber bannorum 1875-1945, k. 19; AALK, sygn. CXIV-3, Metrykalia. Parafia Kuty, Index copulatorum 1782-1945.

${ }^{17}$ AALK, bsygn., Akta Seminaryjne. Akta personalne alumnów 1890-1899 - 1894: Danek Wincenty, Świadectwo ubóstwa Wincentego Danka wystawione przez burmistrza miasta Kuty, Kuty 10 X 1894 r.; Szematyzm królestwa Galicji i Lodomerii z wielkim księstwem krakowskim na rok 1888, Lwów 1888, passim. 
w literaturze drukowanej brak szczegółów na ten temat. Z pośrednich dokumentów pochodzą dane o złożeniu przezeń rządowych egzaminów prawniczych i dopuszczeniu go do funkcji auskultanta sądowego ${ }^{18}$. W zawodzie pracował jedynie przez rok 1893/94 najpierw w sądzie w Niżankowicach k. Mościsk Okręg Sądowy w Jaworowie, a później w Sądzie Krajowym we Lwowie ${ }^{19}$. Znacznie dokładniejsze ustalenia odnoszą się dopiero do okresu formacji ascetyczno-religijnej w Seminarium Duchownym i uniwersyteckich studiów filozoficzno-teologicznych.

Po rezygnacji z kariery sądowej, Wincenty Danek 18 IX 1894 r. wniósł podanie do Konsystorza Metropolitalnego ob. łac. we Lwowie z prośbą o przyjęcie do Seminarium Duchownego ${ }^{20}$. Petycja została pozytywnie rozpatrzona; w roku akad. 1894/95 jego nazwisko pojawia się w spisie alumnów I roku formacji lwowskiego Seminarium Duchownego ${ }^{21}$. Równolegle do statusu alumna otrzymał indeks studenta fakultetu teologicznego Uniwersytetu Lwowskiego. W kolejnych latach 1895/96-1897/98 kontynuował formację ascetyczno-intelektualną we Lwowie ${ }^{22}$. Pomimo pomyślnego finału edukacji, Danek nie przyjął 3 VII 1898 r. święceń kapłańskich jak jego koledzy, ale wskutek kryzysu zdrowotnego udał się na urlop ${ }^{23}$. W latach 1898-1901 odbywał kurację m.in. w Zakopanem, nosząc się nadal z zamiarem wstąpienia

${ }^{18}$ AALK, bsygn., Akta Seminaryjne. Akta personalne alumnów 1890-1899 - 1894: Danek Wincenty, Pismo Wincentego Danka do Konsystorza Metropolitalnego we Lwowie, Lwów 18 IX 1894 r.

${ }^{19}$ Szematyzm królestwa Galicji i Lodomerii z wielkim księstwem krakowskim na rok 1894, Lwów 1894, s. 52, 65; Szematyzm królestwa Galicji i Lodomerii z wielkim księstwem krakowskim na rok 1895, Lwów 1895, s. 52-53.

${ }^{20}$ Dwaj badacze zajmujący się biografią ks. Wincentego Danka: ks. Maciej Józefowicz i prof. Mieczysław Wieliczko przypisują mu posiadanie żony i dwóch synów przed wstąpieniem do Seminarium Duchownego. Mieli oni rzekomo umrzeć wskutek choroby zakaźnej. Po tym fakcie wdowiec zdecydował się wybrać stan kapłański. Tezy tej nie potwierdzają żadne materiały źródłowe, zwłaszcza podanie o przyjęcie do Seminarium Duchownego, które słowem nie wspomina o przeżytej tragedii oraz statusie cywilnym petenta. Wymienieni autorzy informację tę zaczerpnęli zapewne ze wspomnień Polaków pamiętających ks. Danka. Wolno jednak przypuszczać, że doszło tu do znamiennego przeistoczenia faktów: przekaz o śmierci matki oraz dwóch młodszych braci ks. Danka przerobiono na utratę żony i dwojga synów późniejszego kapłana. Tę samą błędną opinię powtarza w swej publikacji Gabriel Szuster. AALK, bsygn., Akta Seminaryjne. Akta personalne alumnów 1890-1899 - 1894: Danek Wincenty, Pismo Wincentego Danka do Konsystorza Metropolitalnego we Lwowie, Kuty 18 IX 1894 r.; M. WieliczKo, Misja ks. Wincentego Danka w świetle dokumentów, „Zeszyty Historyczne PSK im. Józefa Bema na Węgrzech” 2005, z. 2, s. 32; M. JóZEFOWICZ, Ks. kan. Wincenty Danek..., s. 9; TENŻE, Kościót polski w Budapeszcie..., s. 427-428; G. SZUSTER, Wincenty Danek..., s. 23.

${ }^{21}$ Catalogus universi venerabilis cleri saecularis et regularis archidioecesis Leopoliensis rit[us] lat[ini] pro anno Domini 1895, Leopoli 1895, s. 24.

${ }^{22}$ Catalogus [...] 1896-1898, Leopoli 1896-1898, passim.

${ }^{23}$ Catalogus [...] 1898, Leopoli 1898, s. 166. 
w szeregi duchownych archidiecezji lwowskiej ${ }^{24}$. Leczenie okazało się skuteczne, stąd 10 XI $1901 \mathrm{r}$. ówczesny sufragan lwowski arcybiskup tytularny Józef Weber wyświęcił go w wieku 31 lat na kapłana ${ }^{25}$, po czym otrzymał w tym samym miesiącu skierowanie na posadę wikariusza parafii Oleszyce k. Lubaczowa ${ }^{26}$. Spędził tam trzy lata pełniąc standardowe obowiązki duszpastersko-katechetyczne.

Kolejną placówką duszpasterską ks. Wincentego była parafia Opryłowce dekanat tarnopolski, którą objął w charakterze wikariusza w 1904 r. ${ }^{27} \mathrm{~W}$ lipcu 1905 r. rezydując nadal w Opryłowcach został mianowany ekspozytem w Berezowicy ${ }^{28}$, obsługując początkowo tamtejszych wiernych ex currendo, a w roku 1907 osiadł wśród nich, co ułatwiało mu wykonywanie misji pastoralnej ${ }^{29}$. Na ten okres przypadła śmierć ojca, który zmarł 15 XI 1906 r. w Kutach ${ }^{30}$. W Berezowicy ks. Danek spędził niecały rok ${ }^{31}$, bowiem latem 1908 r. wyjechał do Budapesztu z misją duszpasterską wśród tamtejszej Poloniii ${ }^{32}$. Na Węgrzech spędził łącznie 37 lat życia; zmarł 27 IV 1945 r. w Budapeszcie ${ }^{33}$.

Zasadniczym zadaniem 38-letniego w chwili przybycia na Węgry ks. Danka miało być zorganizowanie stacjonarnego duszpasterstwa polonijnego $\mathrm{w}$ stolicy tegoż kraju. Zadanie to ułatwiało mu kilka niewątpliwych atutów: prawdopodobnie elementarna znajomość języka węgierskiego, wykształcenie prawnicze, dojrzałość emocjonalna oraz doświadczenie pastoralne. Wprawdzie nie znał lokalnego środowiska ani tamtejszych uwarunkowań państwowo-kościelnych, ale dość szybko nawiązał niezbędne kontakty. Niezwykle silne oparcie miał

\footnotetext{
${ }^{24}$ Zob. dokument 1 niniejszej edycji.

${ }^{25}$ M. Józefowicz nie zna tej informacji, mimo że dostępna jest we lwowskim schematyzmie. M. Józefowicz, Ks. kan. Wincenty Danek ..., s. 10; Catalogus [...] 1902, Leopoli 1902, s. 171.

${ }^{26}$ Catalogus [...] 1902, Leopoli 1902, s. 102, 182.

${ }^{27}$ Błędna informacja ks. M. Józefowicza przesuwającego nominację o rok później. M. JózEFOwICZ, Kościót polski w Budapeszcie..., s. 428; Catalogus [...] 1905, Leopoli 1905, s. 190.

${ }^{28}$ Catalogus [...] 1906, Leopoli 1906, s. 145, 191.

${ }^{29}$ Catalogus [...] 1908, Leopoli 1908, s. 165.

${ }^{30}$ AALK, sygn. CXIV-7, Metrykalia. Kuty, Status animarum 1901-1945.

${ }^{31}$ Błędną datę 1907 r. podaje ks. Józefowicz w cytowanej już publikacji - Kościót polski w Budapeszcie..., s. 428.

${ }^{32}$ Datę wyjazdu kapłana na Węgry zarówno ks. Maciej Józefowicz, jak i Mieczysław Wieliczko błędnie przesuwają na rok 1907. Tymczasem w schematyzmie archidiecezji lwowskiej z roku 1908 na marginesie danych dotyczących ekspozytury Berezowica Mała znajduje się odręczna notatka kurialnego urzędnika: „R. Danek Vinc. e Berezowica ad Budapest eius loco 5249, 20/7 R. Bialikiewicz Carolus". Ponadto sam ks. Danek potwierdził swój pierwszy rekonesans na Węgrzech latem 1908 r. Catalogus [...] 1908, Leopoli 1908, s. 165; Catalogus [...] 1909, Leopoli 1909, s. 202; M. Józefowicz, Kościót polski w Budapeszcie ..., s. 428; M. WieliczKo, Misja ks. Wincentego Danka..., s. 32; zob. dokument 2 niniejszej publikacji.

${ }^{33}$ M. Józefowicz, Kościót polski w Budapeszcie..., s. 433.
} 
w dotychczasowym swoim zwierzchniku, metropolicie lwowskim abp. Józefie Bilczewskim $^{34}$, przynależnym do grona rzymskokatolickiego episkopatu monarchii austro-węgierskiej, wybitnym uczonym, znakomitym duszpasterzu i propagatorze akcji katolicko-społecznej pod egidą Kościoła ${ }^{35}$. Co więcej, ks. Danek uznał za pierwszorzędny postulat swojej misji budowę świątyni, wokół której miało koncentrować się i funkcjonować życie religijne Polaków. Arcybiskup Bilczewski zaś od zarania rządów w archidiecezji lwowskiej za jeden z ważniejszych aspektów zdynamizowania pastoralnego wiernych uznał konieczność rozwoju sieci parafialnej z własnymi kościołami i zapleczem kulturalnym $^{36}$. Tak więc spotkało się dwóch entuzjastów-społeczników o podobnych wizjach, choć realizowanych w nierównomiernej skali: ks. Danek w obrębie stołecznego miasta jednej z ważniejszych prowincji monarchii, abp Bilczewski na obszarze rozległej archidiecezji lwowskiej w Galicji Wschodniej.

Jednym z aspektów misji pastoralnej abp. Józefa Bilczewskiego była troska o mieszkańców Galicji, poszukujących pracy poza rodzinnymi środowiskami życia. Część z nich w drugiej połowie XIX wieku skierowała swe kroki ku innym prowincjom monarchii austro-węgierskiej, m.in. na Węgry. Ważnym ośrodkiem polonijnym była polska wspólnota w Budapeszcie dysponująca kilkoma stowarzyszeniami społeczno-kulturalnymi i zawodowymi ${ }^{37}$. Nie

${ }^{34}$ Józef Bilczewski (1860-1923) - święcenia kapłańskie w 1884 r. w Krakowie, 1884-1885 wikariusz par. Mogiła, 1885-1888 studia w Krakowie, Wiedniu, Rzymie i Paryżu, w 1886 r. doktorat z teologii, 1888-1889 wikariusz par. Kęty, 1889-1891 wikariusz par. pw. Wszystkich Świętych i katecheta Gimnazjum św. Anny w Krakowie, w 1890 r. habilitacja z teologii, 1891-1900 prof. teologii dogmatycznej na Wydziale Teologicznym Uniwersytetu Lwowskiego, w roku akad. 1896/97 dziekan fakultetu, w roku akad. 1900/01 rektor uczelni; 30 X 1900 r. mianowany przez cesarza Franciszka Józefa metropolitą lwowskim obrządku łacińskiego, prekonizacja papieska 17 grudnia t.r., sakra biskupia oraz ingres do katedry lwowskiej 20 I 1901 r. Autor publikacji naukowych z dziedziny teologii, archeologii chrześcijańskiej, wydawca licznych listów pasterskich, propagator czci Najświętszego Sakramentu, kultu NMP i świętych, protektor budowy kościołów, prekursor akcji katolicko-społecznej, szerzenia oświaty i prasy katolickiej. Zmarł 20 III $1923 \mathrm{r}$. we Lwowie, pochowany na Cmentarzu Janowskim, 19 IV 2011 r. ekshumowany i złożony we lwowskiej Bazylice Metropolitalnej; beatyfikowany 26 VI 2001 r., kanonizowany 23 X 2005 r. ,, Nic dla siebie, wszystko dla Boga i bliźniego". Święty arcybiskup Józef Bilczewski we wspomnieniach, oprac. J. Wołczański, Lwów-Kraków 2016, passim; J. WoŁCZAŃSKI, Biogram i bibliografia prac drukowanych błogosławionego Józefa Bilczewskiego za lata 1888-1929, [w:] Błogosławiony Józef Bilczewski arcybiskup metropolita lwowski obrzadku łacińskiego. Sesja naukowa na Uniwersytecie Jagiellońskim, Kraków 4-5 czerwca 2002, red. J. Wołczański, Kraków 2003, s. 17-47.

${ }^{35}$ M. DęBOwSKA, Akcja społeczna w archidiecezji lwowskiej za rządów arcybiskupa Józefa Bilczewskiego (1901-1923), „Archiwa, Biblioteki i Muzea Kościelne” 1992, t. 61, s. 227-374.

${ }^{36} \mathrm{~W}$ ciągu 23-letnich rządów w archidiecezji lwowskiej abp Bilczewski patronował budowie 328 kościołów i kaplic, ponadto erygował 21 parafii i 96 ekspozytur. M. TARNAWsKI, Arcybiskup Józef Bilczewski. Krótki rys życia i prac, Lwów 1923, s. 52.

${ }^{37}$ M. WieliczKo, Statuta Stowarzyszenia Polaków zamieszkatych w Budapeszcie pod nazwa „Stowarzyszenie Bratniej Pomocy” (A Pestudán lakó Lengyelek Testvér-segélyzó Egyeletének 
posiadał jednak ani odrębnej świątyni, ani też stałego duszpasterza, choć wierni nieformalnie gromadzili się w zniszczonej kaplicy fundacji rodziny Contich w dzielnicy Kőbánya, obsługiwanej przez sporadycznie przybywających na „misje” polskich duchownych, bądź też uczęszczali do kościołów węgierskich ${ }^{38}$. Swego rodzaju przełomem $\mathrm{w}$ historii formowania się polskiego ośrodka w stolicy Węgier okazała się wizyta abp. Bilczewskiego w 1905 r., choć brak o niej wzmianki na łamach podręcznego dziennika hierarchy ${ }^{39}$. Zrodziła się wówczas idea zorganizowania tam standardowego duszpasterstwa polonijnego pod kierunkiem kapłana $\mathrm{z}$ archidiecezji lwowskiej posługującego się m.in. językiem węgierskim. Nie wiadomo, czy ks. Danek posiadał wystarczającą znajomość tego języka; zresztą nigdy nie nauczył się go w dostatecznym wymiarze ${ }^{40}$. Nie sposób też ustalić, z czyjej inspiracji doszło do wyjazdu tegoż duchownego do Budapesztu: metropolity lwowskiego, czy była to decyzja samego kapłana. Ostatecznie latem 1908 r., w okresie translokacji kapłanów, opuścił więc swoją dotychczasową posadę udając się do metropolii naddunajskiej ${ }^{41}$. Pierwszy rekonesans - jak wcześniej wspomniano - odbył w pierwszej połowie czerwca 1908 r., rozpoznając najpilniejsze potrzeby pastoralne oraz nawiązując kontakt z miejscowymi duszpasterzami obcych narodowości ${ }^{42}$. Dość szybko powrócił jednak w granice archidiecezji lwowskiej, po czym we wrześniu tegoż roku już na stałe osiadł w X dzielnicy Budapesztu Kőbánya, usytuowanej na wschód od centrum miasta, pod adresem Kelemen utca $32^{43}$. Odtąd niemal jedyną formą kontaktu ks. Danka z abp. Bilczewskim stała się korespondencja ${ }^{44}$. Do naszych czasów zachowały się łącznie 53 listy adresowane do Lwowa z lat 1900-1919. Niestety, prawdopodobnie żadne pismo metropolity lwowskiego do polonijnego duszpasterza nie przetrwało próby czasu. Wspomniana korespondencja ks. Danka zawierająca interesujące wątki stanowi przedmiot niniejszej edycji.

\footnotetext{
Alapszábalyai, Budapest 1874), „Rocznik Polonijny” 1984/85, nr 5-6, s. 277-286; TENŻE, Ksiadz Wincenty Danek (1870-1945), ,Studia Polonijne” 17 (1996), s. 173-175.

${ }^{38}$ M. WielicZKo, Ksiądz Wincenty Danek..., s. 175.

${ }^{39}$ AALK, bsygn., J. Bilczewski, Dziennik 1900-1923, Lwów 1900-1923, mps, passim.

40 Świadectwa jeszcze żyjacych parafian polskich $i$ wegierskich, „Zeszyty Historyczne PSK im. Józefa Bema na Węgrzech" 2005, z. 2, s. 25, 27.

${ }^{41}$ Catalogus [...] 1908, Leopoli 1908, s. 165; zob. dokument 2 niniejszej publikacji.

${ }^{42}$ Zob. dokument 2 niniejszej publikacji.

${ }^{43}$ Zob. dokument 3 niniejszej publikacji.

${ }^{44}$ Jest to jedyny ślad relacji kapłana $\mathrm{z}$ arcybiskupem. Należało oczekiwać, iż odzwierciedlenie owych więzów znajdzie się w podręcznym dzienniku metropolity. Nie ma tam jednak żadnej wzmianki na ten temat.
} 
W publikowanych niżej dokumentach występuje kilka kręgów tematycznych. Najwięcej uwagi ks. Danek poświęca zagadnieniu budowy tzw. polskiego kościoła w Budapeszcie. Zabiegając o pozyskanie parceli, prosił w czerwcu 1908 r. abp. Bilczewskiego o pismo do burmistrza Pesztu, dr. Istvána Bárczy, aby ten przekazał na rzecz polskiej wspólnoty stosowną działkę ${ }^{45}$. Dwa lata później informował lwowskiego hierarchę o pozytywnych skutkach jego interwencji u burmistrza ${ }^{46}$. W roku 1909 sugerował swemu przełożonemu skierowanie adresu do cesarza Franciszka Józefa celem uzyskania akceptacji dla planowanej inwestycji, co pozwoliłoby usunąć ewentualne zastrzeżenia ze strony węgierskiego Ministerstwa Spraw Wewnętrznych ${ }^{47}$. Wiosną 1909 r. wniósł do tegoż ministerstwa petycję o zatwierdzenie statutów Związku Budowy Kościoła, co nastąpiło dopiero 11 VI 1913 r. ${ }^{48} \mathrm{~W}$ trosce o znalezienie mieszkania w dzielnicy Kőbánya, podsuwał lwowskiemu metropolicie pomysł interpelacji u znanego węgierskiego przemysłowca Antona Drehera, dysponującego w Budapeszcie licznymi nieruchomościami ${ }^{49}$. Nalegał na abp. Bilczewskiego, aby ten poprzez polską reprezentację w wiedeńskiej Izbie Panów uzyskał u tegoż potentata finansowego parcelę pod tzw. polski kościól ${ }^{50}$. Wykorzystywał każdą okazję, aby poprzez wpływy metropolity w sferach rządowych, kościelnych i arystokratycznych monarchii austro-węgierskiej zdobyć protektorów i finanse do realizacji zamierzonych inwestycji ${ }^{51}$.

W żmudnym procesie pozyskiwania środków finansowych ks. Danek nie był bynajmniej zachłannym petentem dbałym wyłącznie o własne cele; umiał okazać wdzięczność ofiarodawcom, choć inteligentnie sięgał po wypróbowane pośrednictwo abp. Bilczewskiego. I tak apelował do metropolity o wyjednanie w Stolicy Apostolskiej stosownego odznaczenia dla szefa sekcji w węgierskim Ministerstwie Wyznań i Oświaty Lipóta Árpáda Várady, zasłużonego dla miejscowej Polonii, a potem pilnował doręczenia mu orderu ${ }^{52}$. Na podobne wyróżnienia zasługiwał - zdaniem ks. Danka - Anton Dreher, o ile przekaże pod budowę kościoła odpowiednią działkę ${ }^{53}$. Wiosną 1916 r. przesłał swemu protektorowi i dobroczyńcy do Lwowa kilka obrazów i paramenty liturgiczne

\footnotetext{
${ }^{45}$ Zob. dokument 2 niniejszej publikacji.

${ }^{46}$ Zob. dokument 23 niniejszej publikacji.

${ }^{47}$ Zob. dokument 7 niniejszej publikacji.

${ }^{48}$ Tamże; M. WieliczKo, Misja ks. Wincentego Danka..., s. 33.

${ }^{49}$ Zob. dokumenty 4 i 5 niniejszej publikacji.

${ }^{50}$ Zob. dokument 21 niniejszej publikacji.

${ }^{51}$ Zob. dokumenty 13, 14, 19, 20, 28, 30, 38 niniejszej publikacji.

52 Zob. dokumenty 17-18, 22 niniejszej publikacji.

${ }^{53}$ Zob. dokument 9 niniejszej publikacji.
} 
dla zniszczonych wojną kościołów w archidiecezji lwowskiej ${ }^{54}$. Pod koniec tegoż roku prosił abp. Bilczewskiego o dostarczenie mu fotografii zdewastowanych świątyń w Galicji Wschodniej celem pokazania ich podczas projektowanego wyjazdu do USA, gdzie zamierzał kwestować nie tylko na rzecz budowy kościoła w Budapeszcie, ale też wesprzeć finansowo renowację dotkniętych wojną obiektów sakralnych swojej macierzystej archidiecezji ${ }^{55}$.

Utrzymując żywą więź z Kościołem lwowskim, kilkakrotnie zabiegał u abp. Bilczewskiego o jego listy pasterskie ${ }^{56}$, postulował akcję przygotowania przez polskich malarzy wizerunków polsko-węgierskich świętych dla ozdobienia świątyń ${ }^{57}$, rozpaczliwie poszukiwał $w$ szeregach duchowieństwa lwowskiego, ale także wśród zakonników kandydatów chętnych do pracy wśród węgierskiej Polonii ${ }^{58}$. Z radością informował metropolitę o entuzjastycznym wręcz przyjęciu, jakie zgotowali mu polscy robotnicy po przyjeździe do Budapesztu ${ }^{59}$. Dzielił się swymi doświadczeniami z dziedziny pracy duszpasterskiej, zwłaszcza odnośnie do asystowania przy zawieraniu przez żyjących dotąd w konkubinacie rodaków związków małżeńskich, częstych i licznych spowiedzi ${ }^{60}$, wyszukiwania w fabrykach i kopalniach zatrudnionych tam Polaków z zachętą do uczestnictwa w życiu religijno-społecznym polskiej społeczności w Budapeszcie ${ }^{61}$. Przed wybuchem I wojny światowej oczekiwał latem 1914 r. planów kościoła zamówionych u architekta i profesora Politechniki Lwowskiej Adolfa Szyszko-Bohusza ${ }^{62}$. W realizacji zamiarów przeszkodziły działania wojenne oraz brak środków finansowych, jak też dewaluacja zebranych już funduszy. Dopiero kwesta ks. Danka w USA w 1923 r. pozwoliła doprowadzić wieloletnie starania do szczęśliwego finału: w 1926 r. miało miejsce poświęcenie świątyni pod wezwaniem Matki Bożej Wspomożycielki Wiernych, a dwa lata później aktu konsekracji dokonał prymas Polski kard. August Hlond ${ }^{63}$. Żadnej z tych uroczystości nie doczekał abp Józef Bilczewski, bowiem zmarł wiosną 1923 r. we Lwowie.

\footnotetext{
${ }^{54}$ Zob. dokument 46 niniejszej publikacji.

${ }^{55}$ Zob. dokument 48 niniejszej publikacji.

${ }^{56}$ Zob. dokument 12, niniejszej publikacji.

57 Tamże.

${ }^{58}$ Zob. dokumenty 3, 4, 6, 8, 14 niniejszej publikacji.

${ }^{59}$ Zob. dokument 3 niniejszej publikacji.

${ }^{60}$ Zob. dokument 2 niniejszej publikacji.

${ }^{61}$ Zob. dokument 3 niniejszej publikacji.

${ }^{62}$ Ostatecznie autorem projektu był węgierski architekt Aladár Arkay. Zob. dokument 44 niniejszej publikacji; M. WIELICZKo, Misja ks. Wincentego Danka ..., s. 34.

${ }^{63}$ Obaj autorzy podają różne daty: prof. Wieliczko rok 1926, ks. Józefowicz 1928 r. Bardziej wiarygodnym jest pierwszy z nich. M. WIELICZKo, Misja ks. Wincentego Danka..., s. 34; M. JóZEFOWICZ, Ks. kan. Wincenty Danek..., s. 14-18.
} 
Prezentowane niżej dokumenty przechowywane są w Archiwum Archidiecezji Lwowskiej ob. łac. w Krakowie. Znajdują się w odrębnej teczce bez paginacji w spuściźnie po abp. Józefie Bilczewskim. W edycji zastosowano podwójny system znaków: literami alfabetu łacińskiego oznaczono wyjaśnienia techniczne, cyframi arabskimi informacje merytoryczne. Oprócz korespondencji ks. Danka zamieszczono kilka innych dokumentów w aneksie oraz materiał ilustracyjny.

\section{PUBLIKACJA ŹRÓDEŁ}

\section{Dokument 1}

$\mathrm{J}[\mathrm{ezus}]^{\mathrm{a}} \mathrm{M}$ [aryja] J[ózef]

Najprzewielebniejszy Księże Arcybiskupie!

Przyłączając się do chóru życzeń, z jakimi spieszą wszyscy z powodu nominacji Jego Magnificencji Najprzewielebniejszego Księdza Rektora ${ }^{64}$, jako dawny uczeń, śmiem w ustroniu zakopiańskim prosić Najwyższego, ażeby niezapomniane nigdy z uniwersyteckiej ławy wrażenia czci i uwielbienia dla naszego Profesora wzmocniły się i uzwoiły więzami posłuszeństwa i uczuciami synowskiego przywiązania dla naszego Arcypasterza.

W tej tedy myśli, nie wyłączając się spod władzy dotychczasowych Przełożonych moich, oddaję z otucha i zaufaniem losy moje i sprawę powołania mego w dostojne ręce Najprzewielebniejszego Księdza Arcybiskupa i pozwalam sobie liczyć na Jego światłą radę, pomoc i poparcie. Przy wciąż słabym zdrowiu trudno mi żywić nadzieję, ażebym mógł odpowiedzieć wszystkim obowiązkom kapłańskim, niemniej przeto pragnę służyć Kościołowi i w tym - tuszę - nie będę pozbawionym opieki Najprzewielebniejszego Księdza Arcybiskupa, którego pozostaję oddanym sługą - z najgłębszą czcią i poważaniem

W Zakopanem ${ }^{65}, 16$ listopada 1900

Wincenty Danek

kleryk

\footnotetext{
a Tekst pisany czarnym atramentem na jednej stronicy czystego papieru formatu in folio. $\mathrm{Na}$ rewersie nota niebieską kredką ręką archiwisty: „Danek”.

${ }^{64}$ Odniesienie do nominacji byłego profesora Wydziału Teologicznego i rektora Uniwersytetu Lwowskiego ks. Józefa Bilczewskiego na arcybiskupa metropolitę lwowskiego. Cesarz Franciszek Józef dokonał jej 30 X 1900 r., prekonizacja ze strony papieża Leona XIII nastąpiła 17 grudnia t.r., sakra biskupia oraz ingres do katedry lwowskiej miały miejsce 20 I $1901 \mathrm{r}$.

${ }^{65}$ Zakopane - kurort w Tatrach.
} 


\section{Dokument 2}

$\mathrm{J}[\text { ego }]^{\mathrm{b}}$ Ekscelencjo, Najprzewielebniejszy Księże Arcybiskupie!

Z pobytu mego w Peszcie ${ }^{66}$ mam zaszczyt złożyć Jego Ekscelencji Najprzewielebniejszemu Księdzu Arcybiskupowi następującą relację. W Peszcie nie zastałem niestety żadnego z ojców misjonarzy 13-go b.m., mimo to poznałem tamtejszych polskich robotników ${ }^{67}$ w Kőbánii ${ }^{68}$, na Kalwarii ${ }^{69}$ t.j. w „Przyjaźni” na Josefstadt ${ }^{70}$. Poznałem się też bliżej z O. Weiserem ${ }^{71}$, z księżmi: Horwathem ${ }^{72}$, Havliczkiem ${ }^{73}$, Morvuyem $^{74}$, Siklayem $^{75}$, z ks. proboszczem z Nowego Pesztu ${ }^{76}$ itp.

O. Mieloch $\mathrm{TJ}^{77}$ oraz robotnicy w Köbánii i z Josefstadt domagają się jak najrychlejszego przybycia księdza wyznaczonego dla nich. Bardzo im było markotno, że odjechałem. Nadto jest tam wiele spraw niecierpiących zwłoki, które jak najrychlej załatwić potrzeba, t.j. kojarzenie małżeństw dzikich, których zelatorowie bractwa Serca P[ana]

\footnotetext{
${ }^{\mathrm{b}}$ Tekst pisany czarnym atramentem na 4 kartach czystego papieru formatu in folio. Na rewersie nota niebieską kredką ręką archiwisty: „Danek”. W górnej partii karty tytułowej nota niebieską kredką ręką archiwisty: „Borczy” oraz ołówkiem ręką abp. J. Bilczewskiego: „Kochanemu Ojcu do wiadomości i zwrotu † Józef"”. Na rewersie, w górnej partii karty nieczytelne notatki ołówkiem ręką lwowskiego metropolity.

${ }^{66}$ Peszt - wschodnia część głównie mieszkalna Budapesztu na Węgrzech położona na lewym brzegu Dunaju; na prawym brzegu znajduje się Buda. Do 1873 r. obie miejscowości funkcjonowały jako odrębne jednostki. W 1873 r. doszło do połączenia trzech miast: Budy, Pesztu i Ó-Budy; powstał wówczas Budapeszt.

${ }^{67}$ W. DANEK, Robotnicy polscy w Budapeszcie, „Gazeta Podhalańska” 1913, nr 1, s. 9-10.

${ }^{68}$ Köbánya - X dzielnica Budapesztu w środkowo-wschodniej części miasta, w której powstał kościół rzymskokatolicki dla Polonii.

${ }^{69}$ Nazwa miejsca w X dzielnicy Budapesztu Kőbányi, w którym znajdowała się barokowa kapliczka fundacji rodziny Contich na placu Kápolna. M. Józefowicz, Kościół polski w Budapeszcie „Małym Rapperswil”, „Archiwa, Biblioteki i Muzea Kościelne” 1996, t. 65, s. 428.

${ }^{70}$ Josefstadt, węg.: Józsefváros - centralna dzielnica Budapesztu oznakowana numerem VIII.

${ }^{71}$ Osoba niezidentyfikowana.

${ }^{72}$ Osoba niezidentyfikowana.

${ }^{73}$ Havliczek Wincenty - rzymskokatolicki duchowny słowacki, duszpasterz od 1897 r. Słowaków w Budapeszcie, celebrujący nabożeństwa dla Polaków do czasu przybycia tam ks. Wincentego Danka w 1908 r.

${ }^{74}$ Osoba niezidentyfikowana.

${ }^{75}$ Osoba niezidentyfikowana.

${ }^{76}$ Nowy Peszt - część Budapesztu rozciągająca się na prawej stronie Dunaju.

77 Ignacy Marcin Mieloch (1868-1937) - święcenia kapłańskie w 1899 r. w Chyrowie, w Zakonie oo. Jezuitów 1890-1894 wykładowca j. niemieckiego i wychowawca w Zakładzie Naukowo-Wychowawczym w Chyrowie, misjonarz w różnych krajach wśród polskich robotników sezonowych, m.in. na Węgrzech, rekolekcjonista, katecheta i duszpasterz w Karwinie, Nowym Sączu, Stanisławowie, Lwowie i Starej Wsi, 1912-1913 superior domu w Cieszynie, 1919-1922 superior w Pińsku, 1927-1931 superior w Poznaniu. Zmarł w 1937 r. we Lwowie. Mieloch Ignacy Marcin, [w:] Encyklopedia wiedzy o jezuitach na ziemiach Polski i Litwy 1564-1995, oprac. L. Grzebień, Kraków 1996, s. 421.
} 
J[ezusa] w Peszcie mimo nalegań Misjonarzy po ich odjeździe nie załatwiają. Potrzeba nadto wyszukiwać sobie robotników po fabrykach, którzy w czasie misji się nie spowiadali (niektórych z takich jednostek umieją wskazać tamtejsi zelatorowie) i wyspowiadać ich w jakiej ubikacji ${ }^{78}$ zacisznej fabryki, skłoniwszy wprzód do spowiedzi; a nade wszystko potrzeba dokończyć misji nieukończonej przez XX. Misjonarzy Jezuitów - dla ich braku czasu - mianowicie według wskazówki robotników w Köbánii i O. Weisera, w Tatabánii ${ }^{79}$ (ok. +-2 godziny drogi koleją z Pesztu w kopalni węgla) i w Nowym Budzinie $^{80}$, w Tatabánii ma być 3000 Polaków.

Dlatego proszę pokornie Jego Ekscelencję, Najprzewielebniejszego Księdza Arcybiskupa, aby raczył łaskawie wydelegować jednego księdza ze Zgromadzenia XX. Misjonarzy albo jednego z księży katechetów, w czasie wakacji wyjechać na pracę gotowego, który by bądź to ze mną, bądź z innym księdzem we dwójkę pojechał tam (do Tatabánii i do Nowego Budzina) jak najrychlej po zawiadomieniu uprzednim (przez księdza wyjechać mającego) O. Weisera, który postara się o wszystko, co potrzeba u Biskupa podobno w $\operatorname{Raab}^{81}$ (?).

Gdyby J[ego] E[kscelencja], Najprzewielebniejszy Ksiądz Arcybiskup mnie raczył $\mathrm{z}$ drugim księdzem wydelegować, proszę uprzejmie polecić łaskawie X. Dziunikowskiemu $^{82}$ z Milna ${ }^{83}$, aby zastąpił ks. kan[onika] Nowobielskiego ${ }^{84}$ z Opryłowiec ${ }^{85}$, który pragnie wyjechać na lipiec do kąpiel, ks. Dziunikowskiego zaś, o ile by on nie mógł binować w Milnie i w Opryłowcach, zastąpiłby ks. Zaleśny ${ }^{86}$ ze Załoziec ${ }^{87}$ tak jak to

${ }^{78}$ Przestarzałe określenie pomieszczenia, lokalu.

${ }^{79}$ Właściwie: Tatabánya - miasto położone $55 \mathrm{~km}$ na zachód od Budapesztu. Znajdowały się tam pokłady węgla kamiennego, przy którego wydobyciu pracowali m.in. polscy górnicy.

${ }^{80}$ Nowy Budzin - jeden z regionów Budapesztu.

${ }^{81}$ Raab (Györ Raab) - miasto nad Dunajem na Węgrzech.

${ }^{82}$ Walerian Dziunikowski (1873-1962) - święcenia kapłańskie w 1904 r. we Lwowie, 1904-1906 wikariusz par. Brzozdowce, 1906-1907 wikariusz par. Załoźce, 1907-1913 wikariusz ekspozyt par. Milno, 1925-1931 proboszcz par. Milno, 1931-1934 administrator par. Ihrowica, 1934-1944 proboszcz par. Płotycz. W 1945 r. w ramach ekspatriacji wyjechał na Śląsk Opolski: 1945-1962 kapelan Domu Pomocy Społecznej w Prószkowie. Odznaczony godnością kanonika honorowego, Złotym Krzyżem Zasługi (przed 1939 r.) i honorowego radcy duchownego (1954). Zmarł 23 I 1962 r. w Prószkowie. J. WoŁCZAŃSKI, Eksterminacja narodu polskiego i Kościoła rzymskokatolickiego przez ukraińskich nacjonalistów w Małopolsce Wschodniej w latach 1939-1945. Materialy źródtowe, cz. 1, Kraków-Lwów 2005, s. 433.

${ }^{83}$ Milno - wieś w pow. Zborów, woj. Tarnopol.

${ }^{84}$ Jakub Nowobielski (1849-1911) - święcenia kapłańskie w 1875 r. we Lwowie, 1875-1877 wikariusz par. Kozłów, 1877-1879 wikariusz par. Podhajce, 1879-1880 wikariusz par. Śniatyn, 1880-1885 wikariusz par. Kołomyja, 1885-1898 administrator i proboszcz par. Horodenka, 1898-1904 proboszcz par. Monasterzyska, 1904-1911 proboszcz par. Opryłowce. Zmarł 22 VI $1911 \mathrm{r}$. w Opryłowcach. Schematismus (Catalogus) universi venerabilis cleri saecularis et regularis archidioecesis Leopoliensis rit [us] lat[ini] 1876-1912, Leopoli 1876-1912, passim.

${ }^{85}$ Opryłowce - wieś w pow. Zbaraż, woj. Tarnopol.

${ }^{86}$ Dominik Zaleśny (1865-1929) - święcenia kapłańskie w 1892 r. w Zakonie oo. Reformatów, 1892-1893 okres niezidentyfikowany, 1893-1901 przebywał w klasztorze oo. Reformatów 
uczynił ks. Zaleśny w czasie 2 tygodniowej nieobecności księdza w Milnie (przed przyjazdem wyznaczonego wówczas do tej miejscowości księdza Dziunikowskiego).

Ze mną gotów jest pojechać na tę misję ks. Czarkowski ${ }^{88} \mathrm{z}$ Bucniowa ${ }^{89}$, który odbywał już kilkakrotnie misje ludowe wraz z ks. Wierzbickim ${ }^{90}$. Ks. Czarkowskiego zastąpi ks. katecheta z Tarnopola ${ }^{91}\left(\right.$ Lehman $^{92}$ lub ks. Urba $\left.{ }^{93}\right)$.

w Rawie Ruskiej, po sekularyzacji przeszedł do archidiecezji lwowskiej ob. łac.: 1901-1902 wikariusz par. pw. św. Anny we Lwowie, 1902-1903 wikariusz par. pw. św. Mikołaja we Lwowie, 1903-1904 wikariusz par. Tartaków, 1904-1905 wikariusz par. Buczacz, 1905-1909 wikariusz par. Załoźce, 1909-1915? wikariusz ekspozyt par. Kłodno Wielkie, 1915?-1918 ekspozyt par. Zdwórze, 1918-1929 administrator par. Witków Nowy. Zmarł 10 I 1929 r. w Witkowie Nowym. Schematismus [...] 1893-1930, Leopoli 1983-1930, passim.

${ }^{87}$ Załoźce - miasto w pow. Zborów, woj. Tarnopol.

${ }^{88}$ Józef Czarkowski (1864-1928) - święcenia kapłańskie w 1889 r. we Lwowie, 1889-1890 wikariusz par. Tłuste, 1890-1895 wikariusz par. Monasterzyska, 1895-1896 administrator par. Dolina, 1896-1897 administrator par. Bukaczowce, 1897-1898 administrator par. Liczkowce, 1898-1900 administrator par. Załoźce, 1900-1901 administrator par. Ostrów, 1901-1902 wikariusz par. Uhnów, 1902-1911 administrator par. Bucniów, 1911-1924 przebywał w Ameryce Północnej, 1924-1925 wikariusz ekspozyt par. Kotów, 1925-1928 proboszcz par. Litiatyn. Zmarł 9 III 1928 r. w Litiatynie. Schematismus [...] 1890-1929, Leopoli 1890-1929.

${ }^{89}$ Bucniów - wieś w powiecie i woj. Tarnopol.

${ }^{90}$ Franciszek Wierzbicki (1874-1959) - święcenia kapłańskie w 1897 r. we Lwowie, 1897-1898, wikariusz par. Stryj, 1898-1902 wikariusz par. Stanisławów, 1902-1905 wikariusz ekspozyt par. Draganówka, 1905-1918 administrator tamże, 1918-1945 proboszcz par. Rzęsna Polska. W ramach ekspatriacji wyjechał w 1945 r. na tzw. Ziemie Odzyskane: 1945-1946 współpracownik duszpasterzy w par. Szczecin-Wielgowo, 1946-1959 administrator i od 1951 r. proboszcz par. Przytoczna. Odznaczony godnością kanonika honorowego. Zmarł 14 III 1959 r. w Przytocznej. R.R. KUFEL, Słownik biograficzny księży pracujących w Kościele gorzowskim 1945-1956, t. IV, Zielona Góra 2019, s. 66-67.

${ }^{91}$ Tarnopol - miasto wojewódzkie w ówczesnej Galicji (Małopolsce) Wschodniej.

92 Właściwie: Józef Lehmann (1870-1943) - święcenia kapłańskie w 1892 r. we Lwowie, 1892-1894 wikariusz par. Śniatyn, 1894-1899 zastępca katechety Gimnazjum Franciszka Józefa we Lwowie, 1899-1920? katecheta szkół średnich w Tarnopolu, 1920?-1929 katecheta szkół średnich we Lwowie, 1929-1943 emeryt. Zmarł 6 XII 1943 r. we Lwowie Schematismus [...] 1893-1939, Leopoli 1893-1939; Archiwum ks. Józefa Wołczańskiego w Krakowie [dalej: AJWK], bsygn., Spis duchowieństwa i parafii archidiecezji w Lubaczowie 1981, Lubaczów 1981, s. 130 , mps.

${ }^{93}$ Marian Urba (1873-1955) - święcenia kapłańskie w 1896 r. we Lwowie, 1896-1898 wikariusz par. Tłuste, 1898-1901 wikariusz par. Złoczów, 1901-1902 wikariusz par. Stanisławów, II-IX 1902 katecheta w Czerniowcach, 1902-1934 katecheta par. Tarnopol, 1934-1946 emeryt i rezydent w Tarnopolu. W ramach ekspatriacji w 1946 r. wyjechał na Dolny Śląsk osiadając w Ząbkowicach Śląskich: 1946-1949 spowiednik ss. Benedyktynek, 1946-1948 katecheta w Gimnazjum Zawodowym i 1947-1948 w gimnazjum państwowym, 1949-1952 kapelan ss. Boromeuszek w Domu Dziecka „Ognisko Młodych” i w Sanatorium św. Antoniego. Odznaczony Srebrnym Krzyżem Zasługi i godnością kanonika honorowego. Zmarł 24 X 1955 r. w Ząbkowicach Śląskich. Schematismus archidioecesis Leopoliensis ritus latini 1896-1939, Leopoli 1896-1939, passim; Kościót rzymskokatolicki i Polacy w Małopolsce Wschodniej podczas wojny ukraińsko-polskiej 1918-1919. Źródła, t. II, oprac. J. Wołczański, Lwów-Kraków 2012, s. 882. 
II. Według twierdzeń ks. dra Horwatha i Morvuya z Pesztu, miasto ma zburzyć kaplicę quasi ${ }^{94}$ polską na Kőbánii (grunt ten nieintabulowany na rzecz kościoła jest własnością miasta Pesztu). Tramwaj ma tam przechodzić, gdzie jest kościół tzn. „kapolna” na Kőbánii. Dlatego ks. dr Horwath doradził mi prosić J[ego] E[kscelecję] Najprzewielebniejszego Księdza Arcybiskupa o napisanie listu do burmistrza Pesztu z prośbą o podarowanie odpowiedniego kawałka gruntu na kościół polski w Köbánii i odpowiedni zasiłek z funduszów miejskich na budowę tego kościoła. Burmistrz ten - według słów X. Horwatha - będzie się czuł zaszczyconym pismem Jego Ekscelencji, a będąc katolikiem z rodziny pobożnej, sprawę poprze i przychylnie załatwi. (Ludzie w Peszcie obiecali sami zrobić cegłę na ten kościół). Adres podany przez ks. Horwatha do tegoż burmistrza brzmi: Nagyságos, Dr Bárczy István ${ }^{95}$, polgármester, Urnak, Budapest IV, Károlykorut 28 sz.

Pan Dr Bárczy włada dobrze językiem niemieckim. W imieniu Polaków w Peszcie proszę, aby J[ego] E[kscelencja] Najprzewielebniejszy Ksiądz Arcybiskup raczył pozwolić mnie pojechać tam po oktawie Bożego Ciała wraz z innym księdzem mającym mnie na razie dopomóc. Proszę jeno o wszystkie papiery, bez których, tj. bez upoważnienia i pozwolenia rządowego i kościelnego pracy rozpocząć nie mogę. Pomieszkanie jest przyzwoite podobno wspólne z ks. Siklayem, katechetą z Pesztu.

$Z$ najgłębszym poważaniem i czcią, oddany i powolny sługa, pełen wdzięczności za najłaskawsze zaufanie

$\mathrm{p}$ [oczta] Iwanczany ${ }^{96}, 16 / 6[1] 908$

$$
\text { Ks. W[incenty] Danek }
$$

\section{Dokument 3}

$\mathrm{Jego}^{\mathrm{c}}$ Ekscelencjo, Najprzewielebniejszy Księże Arcybiskupie!

W imieniu Polaków wszystkich stanów, klas i zawodów tu zamieszkałych składam Jego Ekscelencji, żywą wdzięcznością owiane podziękowanie za tyle trudów w sprawie kreowania ekspozytury dla polskich robotników w Budapeszcie. Liczna, miła, prawdziwie kapłańska, iście apostolska praca, jaką mam tu do spełnienia, oby tylko Pan Bóg Wszechmocny dał mi ją wykonać należycie! Niech będzie niejaką nagrodą za starania i poświęcenie Jego Ekscelencji w tym celu poniesione. Że się opłaciło dokładać pilności w tej sprawie, niech świadczą słowa O. Jezuity Weizera [sic!], mieszkającego w Peszcie: oto OO. Jezuici starali się także o stanowisko duszpasterskie dla Czechów i Włochów, dość licznie tu przebywających. Jednakże rząd węgierski odpowiedział Jezuitom:

\footnotetext{
${ }^{94}$ Łac.: jakby.

${ }^{95}$ István Bárczy (1866-1943) - prawnik i polityk węgierski, dr prawa, 1906-1918 i 1919-1943 burmistrz Budapesztu, 1919-1920 minister sprawiedliwości, 1920-1931 poseł do Zgromadzenia Narodowego Węgier.

${ }^{96}$ Iwanczany - wieś w pow. Zbaraż, woj. Tarnopol.

c Tekst pisany czarnym atramentem na 5,5 kartach czystego papieru formatu in fiolio. W górnej partii karty tytułowej nota niebieską kredką ręką archiwisty: „Danek”.
} 
„Bądźcie zadowoleni, że macie księdza dla Polaków, innym narodom na to nie pozwolimy".

Był zamiar, aby z wiecu katolickiego w B[uda]peszcie, wysłać telegram hołdowniczy i z podziękowaniem do Jego Ekscelencji od Polaków, zebranych na tym wiecu. Ale ciżba uczestników wiecu i nawał spraw nie pozwoliły docisnąć się do prezydium wiecu. Polak, dr Barański ${ }^{97}$ przemawiał 3 razy na wiecu, tj. 3 razy wygłaszał wykłady. Tym trudniej było z powodu tak żywego udziału tegoż mecenasa w pracach wiecu doprowadzić do porozumienia w sprawie adresu do Jego Ekscelencji.

Robotnicy przyjęli mnie z wielką radością. Na Steinbrucku chciano wyjść naprzeciw mnie z muzyką robotniczą (polską), aby z procesją wprowadzić mnie do kościółka nazajutrz po moim przyjeździe; ledwo się wyprosiłem, nie chcąc czynić rozgłosu w tej dzielnicy. Następnej niedzieli zgotowano mnie bardzo miłe przyjęcie we filii „Przyjaźni" ${ }^{98}$ w V dzielnicy, gdzie kilku robotników i jeden właściciel pracowni krawieckiej, Polak, pięknie, mądrze, patriotycznie i w duchu religijnym przemawiali. W ogóle, we filii „Przyjaźni” jest duch dobry, a zebrania mają cechę familijnego stowarzyszania się.

Jest jednak bardzo wiele do zrobienia. Jeden $\mathrm{z}$ robotników, pensjonowany wachmistrz żandarmerii, pracujący we wielkiej fabryce wagonów Ganza ${ }^{99}$, człowiek rozumny, zauważył, że nie jednego, ale trzech księży polskich tu potrzeba. I słusznie. Gdyby nie pomoc ks. Havliczka, Słowaka, bynajmniej niesuspendowanego (jak tej fałszywej wieści zaprzeczono tu w Konsystorzu), siły moje ani w części by nie wystarczyły. I ta pomoc 65-letniego, nadzwyczaj krzepkiego kapłana, redaktora 3 gazet ludowych, jest małą w porównaniu i w stosunku do tego, co tu zrobić należy. W Starym Budzinie pracuje mnóstwo Polaków po cegielniach, ks. proboszcz i dziekan tamtejszej dzielnicy pozwolił mnie już odprawiać nabożeństwa w jednej kaplicy podmiejskiej i tę kaplicę oddał mnie zupełnie do użytku poza kilku świętami, w które odbywają się pielgrzymki (w święta Matki Bożej) do tej kaplicy, ale jakże ja się rozerwę, kiedy i o Kalwarii, i o Nowym Peszcie potrzeba pamiętać. Niestety, ludzie z powodu zakupów dokonywanych przeważnie jedynie $\mathrm{w}$ niedziele przed godziną $10 \mathrm{z}$ rana nie mogą wcześnie przychodzić na nabożeństwa, zatem o binacji ${ }^{100} \mathrm{z}$ powodu znacznego oddalenia tych dzielnic nie może być mowy. Przykro mi więc, że Polacy być może wkrótce nie będą zadowoleni, wątpię bowiem, czy podołam, a raczej przewiduję, że będę zmuszony w najbliższej przy-

${ }^{97}$ Osoba niezidentyfikowana.

${ }^{98}$ Stowarzyszenie „Przyjaźń” powstało w 1891 r. w Budapeszcie, zrzeszając około 150 pracowników cegielni, młynarzy, rzemieślników, górników i robotników fabrycznych dzielnic Ferencváros, Csepel i Kispest. Funkcję długoletniego prezesa pełnił krawiec Jan Magdaliński. W 1908 r. utworzono w dzielnicach V, VI i VII filę „Przyjaźni” pod nazwą „Jutrzenka”, a w 1912 r. stowarzyszenie katolickie „Ranna Jutrzenka”, prowadzące działalność religijną, narodową i samopomocową. Przetrwało ono do II wojny światowej. Źródło: www.bem.hu〉Historia, Zalążki i rozkwit ruchu polonijnego - Bem Egyesület [dostęp: 2 XI 2020].

${ }^{99}$ Węgierska fabryka pojazdów Ganz vállalatok powstała w 1844 r. Nazwa podchodzi od Ábraháma Ganza - węgierskiego inżyniera i producenta żelaza urodzonego w Szwajcarii.

${ }^{100}$ Binacja - dwukrotna msza św. w ciągu dnia celebrowana przez jednego kapłana. 
szłości udać się o pomoc do księży katechetów-Słowaków, aby odprawiali np. na Kalwarii, nabożeństwo, ja zaś pragnę wyjeżdżać do Starego Budzina i N[owego] Pesztu, bo tam najbiedniejsza Polonia, najbardziej zaniedbana. $\mathrm{W}$ innych dzielnicach zaś skutkiem tego ucierpią Polacy, boć nie tylko nie będą mieć nauki regularnej w ojczystym swym języku, ale nadto będą zmuszeni do składek, aby mogli mieć u siebie nabożeństwo słowackie. Podobnie też chcąc niezgodę pomiędzy dwiema stronami załatwić, człowiek z konieczności zazwyczaj naraża się jednej z nich. Dlatego to, gdy bawiąc też po raz pierwszy wysłany przez Jego Ekscelencję przed dwoma miesiącami wdałem się w taką sprawę, a raczej zaledwo oświadczyłem gotowość pośredniczenia, a już zraziłem ku sobie jednego z robotników, który podobno nawet miał pisać do Jego Ekscelencji (jeszcze przed moim powtórnym przyjazdem do B[uda]pesztu), aby Jego Ekscelencja nie mnie, lecz kogo innego tu przysłał. Teraz ten robotnik już się udobruchał. Przepraszam też Jego Ekscelencję pokornie, że wysyłając przekaz do N[a]jprz[ewielebniejszego] Ordynariatu dopisałem parę słów na odcinku w charakterze konfidencjonalnym, przypuszczałem bowiem, że słowa te odczyta tylko ks. notariusz Konsystorza, mój kolega ze seminarium.

Sprawa listu do Dra Bárcza, burmistrza Pesztu z tym, aby On darował plac na budowę kościółka na Steinbrucku i wyjednał pewną zapomogę w radzie miasta na ten cel nie schodzi z porządku dziennego i o list taki w języku niemieckim Jego Ekscelencję w pokorze upraszam.

$\mathrm{Z}$ najgłębszą czcią pozostaję oddanym w Bogu z synowską uległością, jakoby jeszcze obecnie dla Swego Arcybiskupa, uszczęśliwiony i uczczony przez Jego Ekscelencję tą misją wielką, pozostaję i kreślę się sługą i duchownym synem wielkiej, polskiej duszy Jego Ekscelencji, którą o modlitwę pokornie proszę, abym choć w części sprostał zadaniu.

\section{Ks. Wincenty Danek}

Budapeszt, X Kelemen utca, 32

23 września 1908

\section{Dokument 4}

Jego ${ }^{\mathrm{d}}$ Ekscelencjo, Najprzewielebniejszy Księże Arcybiskupie!

Ośmielam się pokornie prosić, aby Jego Ekscelencja, Najprzewielebniejszy Ksiądz Arcybiskup raczył w dobroci Swojej wracając na Wiedeń do Lwowa wstąpić łaskawie do pana Drehera ${ }^{101}$, właściciela kilku browarów (jednego na Kőbányi w Budapeszcie),

\footnotetext{
d Tekst pisany czarnym atramentem na 4 kartach czystego papieru formatu in folio. W górnej partii karty tytułowej nota niebieską kredką ręką archiwisty: „Danek”.

${ }^{101}$ Anton Dreher (1849-1921) - absolwent Politechniki w Zurychu, wyznania rzymskokatolickiego, przemysłowiec, właściciel browarów „Anton Drehers Brauerei AG” m.in. na Węgrzech o światowej renomie, filantrop, 1909-1921 dyrektor pierwszej austriackiej Kasy Oszczędności
} 
członka delegacji austr[iacko]-węgierskiej, podobno też członka Izby Panów z tym, aby tenże milioner, hojny zresztą $\mathrm{w}$ takich razach ofiarował pewną sumę pieniężną na rzecz budować się mającego kościoła dla Polaków Köbányi.

Zapewniano mnie, że gdy p[an] Dreher w mieszkaniu swoim (Klein-Schwechet Drehersche Bierbrauerei) - pół godziny drogi od śródmieścia Wiednia oddalonym - ujrzy takiego Dygnitarza kościelnego - to nie poskąpi ofiary.

Dopiero po udanym załatwieniu tej sprawy, tym łatwiejszej do przeprowadzenia, że u p[ana] Drehera w Budapeszcie na Kőbányi pracuje bardzo wielu Polaków - spokojnych i pracowitych - oraz wielu Rusinów, którzy także do kościółka na Kőbányi uczęszczają na nabożeństwa; gdy uda się ta wielkim sercem podjęta misja proszę, aby Jego Ekscelencja wchodząc $\mathrm{w}$ przykre położenie moje z powodu braku odpowiedniego mieszkania raczył wspomnieć temuż p[anu] Dreherowi, czy nie byłby on skłonnym odstąpić mnie kąt jaki w swoim lub syna swego domu, wzgl[ędnie] pałacu, ile że oba te pomieszkiwania, a przynajmniej jedno z nich przez większą część roku jest próżne. Grzeczność nie byłaby dożywotnią, gdyż jeżeli gmina wyznaczy plac oddalony od tzw. Kapolna ter ${ }^{102}$ - to $\mathrm{i}$ ja będę zmuszony szukać pomieszkania w pobliżu nowego budować się mającego kościoła.

II. Co do drugiego księdza polskiego w Budapeszcie są 2 plany.

1) Ks. Dr Pokorny ${ }^{103}$, profesor gimnazjalny i prezes stowarzyszenia dla rzemieślników, odstępuje nowo postawiony gmach tzw. Kat[olicki] Egyesület (na Budzinie) zakonnikom, którzy by zobowiązali się prowadzić ten zakład, częściowo przyszły internat dla rzemieślniczej młodzieży rozumie się węgierskiej. Księża Salezjanie z Turynu ${ }^{104}$ (i okolicy) odmówili i nie przyjęli propozycji. Gdyby Księża Zmartwychwstańcy podjęli się tego dzieła nakazawszy kilku (2-3) swoim członkom nauczyć się języka węgierskiego, to jeden z nich - rozumie się Polak - mógłby częściowo obsługiwać robotników polskich w tej części Budapesztu zamieszkałych. Ks. Pokorny utrzymuje, że 300 fl[orenów] rocznie lub więcej znalazłyby się dla 2 lub 3 zakonników (t.j. po 300 fl[orenów] dla każdego). Adres do tego gorliwego kapłana jest: Budapest, I Toldy Ferencz utca 30.

2) Gdy atoli ta sprawa z konieczności musi się przewlec przeto upraszam, aby Jego Ekscelencja raczył po porozumieniu się z O[jcem] Generałem Braci Mniejszych w Rzymie wyjednać, aby jeden z wypróbowanych tychże Braci Mniejszych czyli Bernardynów, Polak, przybył do Budapesztu - Orsza gut, II Margitkőrut 23, aby tu zamieszkawszy w klasztorze Braci Mniejszych tu Franciszkanami zwanych - mógł działać jako kapelan względnie misjonarz dla Polaków. W tej właśnie dzielnicy i w tym klasztorze

w Wiedniu, kawaler Orderu Franciszka Józefa, kawaler II klasy Orderu Żelaznej Korony, od 1902 r. członek wiedeńskiej Izby Panów. Z małżeństwa z Katarzyną Meichl miał trzech synów. Źródło: Anton Dreher - Wikipedia, en.wikipedia.org〉wiki〉Anton_Dr [dostęp: 16 XI 2020].

${ }^{102}$ Węg.: park.

${ }^{103}$ Osoba niezidentyfikowana.

104 Turyn - miasto w północno-zachodnich Włoszech; na przedmieściach miasta ks. Jan Bosko otworzył swoje pierwsze Oratorium dla młodzieży. 
mieszkając mógłby ksiądz polski bardzo wiele dobrego zrobić, mając gwardianem najprzychylniejszego i najczynniejszego $\mathrm{w}$ sprawie uzdrowienia wielu dzikich małżeństw, także pomiędzy Polakami pracującego mimo nieznajomości języka O. Kaize$\mathrm{ra}^{105}$, który jednak jako proboszcz zarazem nad 10000 dusz zbyt wiele ma zajęcia, aby mógł jakby potrzeba w przyległych także dzielnicach pracować i dla Polaków podejmować się dobrowolnej misji. W klasztorze jest miejsce wolne, gorliwość O. Gwardiana każe mi przypuszczać, że on nie będzie się sprzeciwiał, o tym jednak jeszcze pozwolę sobie donieść Jego Ekscelencji.

Przykro mnie, że Najprzewielebniejszego Księdza Biskupa Nowaka ${ }^{106}$ nie przyjąłem odpowiednio, drugim razem (być może otrząsnąwszy się nieco z pilnej pracy) będę się starał poprawić w gościnności. Proszę uprzejmie sumę ofiarowaną od dziekana niepotrzebną pilnie polecić złożyć $\mathrm{w}$ jednym $\mathrm{z}$ banków.

Z prawdziwą czcią pozostaję i poważaniem najwyższym, prosząc, jeśli można, o uprawnienia quasi misyjne dla mnie u Stolicy Apostolskiej, non obstantibus iuribus Ordinarii ${ }^{107}$.

Wdzięczny i oddany sługa

Budapest, X Kelemen utca 32

Ks.Wincenty Danek

5/IX 1908

\section{Document 5}

$\mathrm{Jego}^{\mathrm{e}}$ Ekscelencjo, Najprzewielebniejszy Księże Arcybiskupie!

Proszę uprzejmie, aby Jego Ekscelencja raczył sprawę mojego mieszkania w zabudowaniach p[ana] Antoniego Drehera, właściciela browaru (we Wiedniu i) w Budapeszcie poruczyć łaskawie jednemu z Wiel[ebnych] Ojców Zmartwychwstańców we Wiedniu, ile że osobista interwencja więcej zdziała aniżeli moja listowna u p[ana] Drehera prośba.

Prosząc o włączenie mnie w zakres osób, którym Jego Ekscelencja błogosławić zwykł, pozostaję oddanym z najwyższą czcią sługą

B[uda]pest X, Kelemen utca 32

Ks. W[incenty] Danek

16/XI [1]908

${ }^{105}$ Pomyłka autora; powinno być: Weisera.

${ }^{106}$ Anatol Nowak (1862-1933) - krakowski duchowny rzymskokatolicki, 1900-1924 biskup pomocniczy diecezji krakowskiej, 1901-1912 rektor Seminarium Duchownego w Krakowie, 1924-1933 biskup diecezjalny przemyski. P. Nitecki, Biskupi Kościoła w Polsce. Stownik biograficzny, Warszawa 1992, s. 149.

${ }^{107}$ Łac.: niekolidujące z prawami biskupa ordynariusza.

e Tekst pisany czarnym atramentem na jednej karcie czystego papieru formatu in folio. 


\section{Dokument 6}

$\dagger$

Jego $^{\mathrm{f}}$ Ekscelencjo, Najprzewielebniejszy Księże Arcybiskupie!

Do chóru życzeń, zgodną harmonią - będących wyrazem uczuć i przekonań, jakie żywią o Osobie i dla Osoby Jego Ekscelencji ci wszyscy, którzy mieli szczęście zetknąć się z Najprzewielebniejszym Księdzem Arcybiskupem lub otrzymać odeń jakiekolwiek dobrodziejstwo, ja tym skorzej śmiem się przyłączyć, że mnie łaskawość Jego Ekscelencji nie byle jakim zaszczyciła względem.

Aby jednak potomność tak wielbiła zamiary i czyny Jego Ekscelencji jak wielbią obecnie jednego z poprzedników na stolicy Metropolitalnej lwowskiej, bł. Jakuba Strzemię ${ }^{108}$, aby zabiegi Jego Ekscelencji tym obfitszym uwieńczone były u Boga i u ludzi plonem, proszę o poparcie w sprawie pomocniczej siły duszpasterskiej dla Polaków w Budapeszcie.

Starania moje u OO. Zmartwychwstańców i Pallotynów nie przyniosły pomyślnego rezultatu. Świeżo napisałem do OO. Paulinów w Częstochowie. OO. Paulini bowiem przed trzema laty przybyli z Polski do Węgier z zamiarem założenia tu nowicjatu. Powołań nie było. Tymczasem w Nowym Peszcie ks. proboszcz zgadza się na przyjęcie zakonników. Jest i kościół wolny, w którym latem w czasie wakacji odprawiają się nabożeństwa dla „dam angielskich”, które tuż obok mają swą letnią wilegiaturę ${ }^{109}$. W tym kościele ja odprawiam dla Polaków nabożeństwa (raz w miesiącu). W tym kościele i przy nim zakon mógłby rozpocząć swoją działalność - nad wyraz potrzebną. Proszę tedy, aby Jego Ekscelencja raczył na tym liście dodać słowa polecające mnie, jako delegowanego przez Jego Ekscelencję. Inaczej list mój wysłany do OO. Paulinów mniejsze znajdzie zaufanie.

Pozostaję z najgłębszą czcią i wdzięcznością donosząc w końcu, że misje OO. Pallotynów tu udały się.

Wdzięczny i oddany sługa

Ks. Wincenty Danek

15 marca 1909, t.j. w dzień, w którym Węgrzy obchodzą pamiątkę swojej wolności ${ }^{110}$. Budapeszt, X Ohegy utca 2

\footnotetext{
${ }^{\mathrm{f}}$ Tekst pisany czarnym atramentem na 2 kartach czystego papieru formatu in folio. W górnej partii karty tytułowej nota niebieską kredką ręką archiwisty: „Danek”.

${ }^{108}$ B1. Jakub Strzemię/Strepy (1340-1409) - polski franciszkanin, 1391-1409 arcybiskup metropolita halicki, beatyfikowany w 1790 r., od 1909 r. patron archidiecezji lwowskiej; jego kult rozwijał z wielkim rozmachem abp J. Bilczewski. Z perspektywy czasu okazało się, że sława abp. Bilczewskiego przewyższyła jego poprzednika, bowiem jako pierwszy w całych dziejach archidiecezji lwowskiej ob. łac. doczekał się on kanonizacji.

${ }^{109}$ Przestarzałe: urlop spędzany na wsi; potocznie - wypoczynek wakacyjny.

110 Święto narodowe na Węgrzech w rocznicę powstania przeciwko Austrii 15 III 1848 r.
} 


\section{Dokument 7}

$\mathrm{J}[\text { ego }]^{\mathrm{g}} \mathrm{E}[\mathrm{kscelencjo],} \mathrm{Najprzewielebniejszy} \mathrm{Księże} \mathrm{Arcybiskupie!}$

Zlecenie Jego Ekscelencji co do przyjazdu Najprz[ewielebniejszego] Księdza Biskupa Pelczara ${ }^{111}$ wypełniłem.

Dziękuję serdecznie Jego Ekscelencji za łaskawe zapytanie o zdrowie. Nie mogę się skarżyć na zdrowie - przy denerwującej pracy nie znakomite, ale nie najgorsze.

Proszę, ośmielam się prosić, aby Jego Ekscelencja, jako Radca Dworu - w tym właśnie charakterze raczył uprosić listownie lub przy sposobności ustnie naszego Monarchę ${ }^{112}$, aby tenże dał znać tutejszemu ministerstwu spraw wewnętrznych, że on, jako król Węgier a władca całej monarchii akceptuje zamiar postawienia dla Polaków kościoła w Budapeszcie i że jest życzeniem Cesarza, aby tut[ejsze] ministerstwo nie czyniło $\mathrm{w}$ tej sprawie przeszkód, jedynie dla religijnych pobudek podjętej. Wniosłem prośbę do ministerstwa o zatwierdzenie statutów związku dla budowy kościoła. Każdy robotnik płaciłby najmniej 10 centów tygodniowo na ten cel. Informowano mnie, że skoro uznane będzie to, że sprawa nie jest przeciwna interesom kraju węgierskiego, mogę liczyć na zatwierdzenie statutów ${ }^{113}$.

Rzecz tę powierzam potężnej opiece Jego Ekscelencji, którego pozostaję oddanym sługą, z prawdziwą czcią i poważaniem

B[uda]peszt, X Ohegy utca 2

Ks. Wincenty Danek

28 kwietnia 1909

g Tekst pisany czarnym atramentem na 2 kartach czystego papieru formatu in folio. W górnej partii karty tytułowej nota niebieską kredką ręką archiwisty: „Danek”.

111 Józef Sebastian Pelczar (1842-1924) - święcenia kapłańskie w 1864 r. w Przemyślu, dr teologii, dr prawa kanonicznego, 1864-1865 wikariusz par. Sambor, 1868-1869 wikariusz par. Wojutycze i ponownie par. Sambor, w roku akad. 1869/70 prefekt Seminarium Duchownego w Przemyślu, 1870-1877 wykładowca teologii pastoralnej i prawa kanonicznego w Instytucie Teologicznym tamże, 1877-1880 prof. historii Kościoła i prawa kanonicznego na Wydziale Teologicznym UJ w Krakowie, 1880-1899 prof. teologii pastoralnej tamże, w roku akad. 1881/82 i 1885/86 dziekan fakultetu, w roku akad. 1880/81 prorektor i w 1882/83 rektor UJ, od 1880 r. kanonik Kapituły Katedralnej w Krakowie; 1899-1900 biskup pomocniczy przemyski, 1900-1924 biskup diecezjalny tamże. Beatyfikowany 2 VI 1991 r. w Rzeszowie, 18 V 2003 r. kanonizowany w Rzymie. H.E. WYCZAwsKI, Pelczar Józef Sebastian, [w:] Stownik polskich teologów katolickich, t. III, red. H.E. Wyczawski, Warszawa 1982, s. 335-346; Święty Józef Sebastian Pelczar (1842-1924). Rektor Uniwersytetu Jagiellońskiego i biskup przemyski, red. A. Kubiś, J. Wołczański, Kraków 2005, passim; informacje własne autora.

112 Odniesienie do osoby Franciszka Józefa (1830-1916), pełniącego od 1848 r. funkcję cesarza Austrii oraz króla Węgier, Czech i Chorwacji.

${ }^{113}$ Statut Stowarzyszenia Budowy Kościoła pw. Matki Bożej Nieustającej Pomocy został zatwierdzony w 1910 r. M. WielicZKo, Ksiądz Wincenty Danek..., s. 177. 


\section{Dokument 8}

$\mathrm{Jego}^{\text {h }}$ Ekscelencjo, Najprzewielebniejszy Księże Arcybiskupie!

Ośmielam się pisać do Jego Ekscelencji z prośbą w następującej sprawie. Jak wiadomo Jego Ekscelencji, Polacy schodzą się regularnie na nabożeństwa w kilku dzielnicach Budapesztu. Nie mogąc wszystkim wszędzie służyć, upatrzyłem sobie pomocnika w osobie ks. Szpewaka ${ }^{114}$ (Słowak), pensjonowanego ${ }^{115}$ wikarego i redaktora, który gotów jest pomóc mnie pod warunkiem, jeśli mu zapewnię stypendia mszalne podobnie jak on je otrzymuje dotychczas od OO. Franciszkanów co dzień po 2 korony - odprawiając u nich codziennie Mszę św. o stale oznaczonej porze. Porządek tego nabożeństwa u OO. Franciszkanów gotów jest ks. Szpewak zmienić otrzymawszy odpowiednią ilość stypendiów codziennie, gdyż stypendia stanowią dla niego poważne źródło utrzymania wobec skromnej jego pensji. Nie rozporządzając tylu stypendiami udaję się do Jego Ekscelencji z prośbą o pomoc, ile że Polacy zwłaszcza w czasie wakacji - wobec ogromnego braku księży w Budapeszcie - wiele ucierpieli i nie biorą udziału regularnie w nabożeństwie z powodu jego niejednostajności. Odnosi się to do „Kalwarii”. Dotychczas poza wakacjami zastępuje mnie ks[iądz] katecheta, który jednak wcale nie głosi kazań w słowackim języku, zrozumiałym dla tutejszych naszych robotników. Ks. Szpewak zobowiązuje się głosić nauki, za co nasi robotnicy osobno go wynagradzać będą. W Köbányi cieszę się stałą pomocą ks. Havliczka (Słowaka). Pozwoleniem tutej[szego] Konsystorza wykażę się.

Licząc na rychłą odpowiedź z uwagi na zbliżający się rok szkolny, w którym osobno musimy umówić się z ks[iędzem] zastępcą, pozostaję z wyrazami głębokiej czci, poważania i wdzięczności - oddany w Bogu sługa

Budapeszt X Kelemen utca 32

Ks. Wincenty Danek

17 sierpnia 1909

\section{Dokument 9}

Jego ${ }^{i}$ Ekscelencjo, Najprzewielebniejszy Księże Arcybiskupie!

Proszę najusilniej, aby Jego Ekscelencja, Najprzewielebniejszy Ksiądz Arcybiskup, był łaskaw przyrzec wpływem swoim poczynić starania w Rzymie dla zapewnienia

\footnotetext{
${ }^{\mathrm{h}}$ Tekst pisany czarnym atramentem na 2 kartach czystego papieru formatu in folio. W górnej partii karty tytułowej nota czerwoną kredką ręką abp. J. Bilczewskiego: „Int[encje] X. Haschler”, zaś u dołu ostatniej karty nieczytelna nota tegoż ołówkiem.

114 Osoba niezidentyfikowana.

${ }^{115}$ Przestarzałe: emerytowanego.

${ }^{\mathrm{i}}$ Tekst pisany czarnym atramentem na 2 kartach czystego papieru formatu in folio. W górnej partii karty tytułowej nota niebieską kredką ręką archiwisty: „Danek”.
} 
$\mathrm{p}$ [anu] Antoniemu Dreherowi, właścicielowi browarów w Wiedniu (Szwechet) ${ }^{116}$ i w Budapeszcie pewnej odznaki papieskiej na wypadek, gdy tenże $p$ [an] Dreher ofiaruje grunt swój pod budowę kościoła dla Polaków w Budapeszcie. Przeciw p[anu] Dreherowi nie słyszałem żadnych zarzutów odnośnie do prawości jego charakteru i jego katolicyzmu. Owszem, już dawniej okazał on się hojnym na cele kościoła parafialn[ego] węg[ierskiego] w Budapeszcie. Słyszę, że tutejszy Najprzewielebniejszy Ordynariat, a być może także wiedeński Ordynariat, do prośby tej się przyczyni. Obecnie, gdy tut[ejszy] Ordynariat zaszczycił mnie pismem pochwalającym myśl postawienia kościoła dla Polaków w Peszcie, piszę niemal równocześnie listy do p[anów] dr. Głąbińskiego ${ }^{117}$, Kozłowskiego $^{118}$, J[ego] E[kscelencji] Bilińskiego ${ }^{119}$, Madejskiego ${ }^{120} \mathrm{i}$ innych z prośbą, by p[ana] Drehera o ten grunt dość znacznej wartości (około 50000 K[oron]) uprosili.

Proszę tylko, by Jego Ekscelencja, Najprzewielebniejszy Ksiądz Arcybiskup, raczył w życzliwości Swojej szczególnej, tylekrotnie Polonii tutejszej okazanej - skreślić

\footnotetext{
${ }^{116}$ Forma zgodnie z oryginałem; poprawnie: Schwechet.

117 Stanisław Głąbiński (1862-1943) - dr praw, w 1892 r. habilitacja z ekonomii społecznej, w 1892 r. prof. nadzwyczajny na Uniwersytecie Lwowskim, w 1895 r. prof. zwyczajny, 1899-1900 dziekan Wydziału Prawa i Umiejętności Politycznych, w roku akad. 1908/09 rektor uczelni tamże, 1890-1892 zastępca redaktora „Gazety Narodowej”, 1902-1918 poseł do Rady Państwa, 1904-1918 poseł na Sejm Galicyjski, 1910-1918 poseł na Sejm Bukowiński. Związany był ze stronnictwem wszechpolskim, od 1905 r. należał do Stronnictwa Narodowej Demokracji, 1919-1928 zasiadał w Sejmie z ramienia Związku Ludowo-Narodowego, 28 V-14 IX 1923 minister Wyznań Religijnych i Oświecenia Publicznego, 1928-1935 senator. We wrześniu 1939 r. aresztowany przez Sowietów, zmarł w Moskwie. A. Galos, Głąbiński Stanisław, [w:] Polski Stownik Biograficzny, t. VIII, red. zbior., Wrocław-Kraków-Warszawa 1959, s. 102-105; J. GoŁĘBIOwsKi, Gtąbiński Stanistaw, [w:] Kto byt kim w Drugiej Rzeczypospolitej, red. J. Majchrowski, Warszawa 1994, s. 39.

118 Włodzimierz Kozłowski (1858-1917) - dr praw, właściciel dóbr Zabłotce Kozłowskie w pow. przemyskim, 1889-1914 poseł do Sejmu Galicyjskiego; na jego forum zajmował się zagadnieniami budżetowymi, gospodarstwa krajowego, szkolnictwa, 1885, 1902, 1905-1917 poseł do parlamentu wiedeńskiego; w sejmie był przywódcą konserwatywnego klubu „Centrum” opowiadającego się za walką z Ukraińcami oraz sojuszem z endecją, 1889-1902,1905-1917 poseł do Rady Państwa; w Kole Polskim przewodził grupie Podolaków, należał do grona polityków konserwatywnych. J. ZdRADA, Kozłowski Włodzimierz, [w:] Polski Słownik Biograficzny, t. XV, red. zbior., Wrocław-Warszawa-Kraków 1970, s. 39-40.

${ }^{119}$ Leon Biliński (1846-1923) - polski polityk, 1871-1892 profesor ekonomii społecznej Uniwersytetu Lwowskiego, w roku akad. 1878/79 rektor uczelni, od 1883 r. poseł do wiedeńskiej Rady Państwa, prezes Koła Polskiego tamże, 1895-1897 i 1909-1910 minister skarbu, 1912-1915 minister skarbu Austro-Węgier oraz namiestnik cywilny Bośni i Hercegowiny, w 1919 r. minister skarbu w rządzie premiera Ignacego Paderewskiego. Biliński Leon, [w:] Kto byt kim..., s. 32.

${ }^{120}$ Właściwie: Stanisław Jerzy Madeyski (1841-1910) - doktor praw, w 1879 r. habilitacja, 1864-1886 urzędnik sądowy, 1879-1898 poseł do rady Państwa w Wiedniu, 1883-1901 poseł na Sejm Galicyjski we Lwowie, 1893-1895 szef Ministerstwa Wyznań i Oświaty, od 1899 r. dożywotni członek Izby Panów Rady Państwa, autor publikacji z dziedziny prawa, w 1894 r. mianowany tajnym radcą austriackim. P.M. ŻUKowsKI, Profesorowie Wydziału Prawa Uniwersytetu Jagiellońskiego, t. II: 1780-2012, Kraków 2014, s. 311-312; J.S. DunIN-BorkowsKI, Austriaccy radcy tajni w Galicji, Lwów 1901, s. 59-60.
} 
także parę słów do p[ana] Głąbińskiego, prezesa Koła Polskiego w Wiedniu - według uznania Swego - czyniąc nadzieję ze Swej strony poczynienia starań o tę odznakę dla $\mathrm{p}$ [ana] Drehera jako przyszłego fundatora kościoła polskiego w Peszcie. Wobec wielu trudności i prac pomoc ta Jego Ekscelencji, Najprzewielebniejszego Księdza Arcybiskupa, jest dla mnie nieocenienie wielkiej wagi.

Pozostaję z prawdziwą, wielką czcią dla wielkich zalet serca i umysłu i wielkiej godności Jego Ekscelencji oddanym sługą

Budapeszt, X Kelemen utca 32

Ks. Wincenty Danek

$26 \times 1909$

\section{Dokument 10}

Jego ${ }^{j}$ Ekscelencjo, Najprzewielebniejszy Księże Arcybiskupie!

Wobec tylu dobrodziejstw, jakie otrzymałem od Jego Ekscelencji, Najprzewielebniejszego Księdza Arcybiskupa, nie mogę pominąć żadnej sposobności, przy której zwyczajem powszechnym wyraża się swoje uczucia. Dlatego ośmielam się z okazji świąt Zmartwychwstania Pańskiego złożyć Jego Ekscelencji, Najprzewielebniejszemu Księdzu Arcybiskupowi, najszczersze życzenia i donieść zarazem, że statuty stowarzyszenia budowy kościoła polskiego w Budapeszcie wreszcie po długich staraniach uzyskały zatwierdzenie tutejszego ministerstwa spraw wewnętrznych ${ }^{121}$.

Pozwalam sobie prosić Jego Ekscelencję, Najprzewielebniejszego Księdza Arcybiskupa, o rozszerzenie swojej prośby o łaskawą instancję u J[ego] E[kscelencji] p[ana] Marszałka hr. Badeniego ${ }^{122}$, [a] mianowicie, by tenże hrabia wysłał okólnik albo wyraził - ufam - życzliwą opinię swoją w dziennikach nie tylko odnośnie do rad czyli wydziałów powiatowych, ale także w stosunku do urzędów miejskich i magistrackich, a jeśli to możliwe i gminnych, polecając nasze dzieło - w granicach możliwych - ofiarności tych urzędów. Do urzędów miejskich i magistrackich zaniosłem już podania o subwencję i dzięki Bogu nadchodzą do nasz[ego] kasjera, p[ana] Czartoryskiego ${ }^{123} \mathrm{z}$ wolna zapo-

j Tekst pisany czarnym atramentem na 2 kartach czystego papieru formatu in folio. W górnej partii karty tytułowej nota niebieską kredką ręką archiwisty: „Danek”.

${ }^{121}$ Zob. dokument 7 niniejszej edycji.

${ }^{122}$ Stanisław Marcin Badeni (1850-1912) - ziemianin, hrabia, dr praw i dr filozofii, od 1883 r. poseł na Sejm Galicyjski, w 1891 r. wszedł dożywotnio do austriackiej Izby Panów, 1895-1901 i 1903-1912 marszałek Sejmu Galicyjskiego, odznaczony komandorią Orderu Św. Grzegorza, kawaler Wielkiego Krzyża Leopolda, tajny radca austriacki. S. STARZYŃSKI, Badeni Stanisław Marcin, [w:] Polski Stownik Biograficzny, t. I, red. zbior., Kraków 1935, s. 209-211; J.S. DuniN-BorKOWSKI, Austriaccy radcy tajni..., s. 6-7.

${ }^{123}$ Prawdopodobnie: Zygmunt Czartoryski (1853-1920) - ziemianin, ożeniony z Zofią Lubomirską, gospodarował w swych dobrach w Poznańskiem, autor publikacji polemicznych i polityczno-gospodarczych. Zmarł 24 XII 1920 r. w Rokosowie. A. SkAŁKowSKI, Czartoryski Zygmunt, [w:] Polski Stownik Biograficzny, t. IV, red. W. Konopczyński, Kraków 1938, s. 304. 
mogi (5 lub 10 kor[on], od wydziałów pow[iatowych] także 25-50 kor[on]). Do urzędów gminnych gotów jestem także podania wnieść (gdybym mógł z wdzięcznością otrzymać jaką co do tego informację).

Także przesłania niemieckich (2) egzemplarzy listu pasterskiego Jego Ekscelencji o N[ajświętszej] Eucharystii dotychczas oczekuję, składając najżywszą podziękę za przyrzeczenie wysłania tychże.

$\mathrm{Z}$ najgłębszą czcią i poważaniem - oddany sługa

$\mathrm{X}$ Kelemen u[tca] 32

Ks. Wincenty Danek

24 marca 1910

\section{Dokument 11}

$\mathrm{Jego}^{\mathrm{k}}$ Ekscelencjo, Najprzewielebniejszy Księże Arcybiskupie!

Radosne i smutne zmuszony jestem donieść wieści Jego Ekscelencji Najprzewielebniejszemu Księdzu Arcybiskupowi. Oto Jego Świątobliwość Ojciec Św[ięty ${ }^{124}$ udzielił Apostolskiego Błogosławieństwa własnym pismem ofiarodawcom Kościoła polskiego w Budapeszcie, co wkrótce opublikuję ${ }^{125}$.

Do komitetu budowy wstąpiła Jej Królewska Wysokość ks[iężna] Karolina Bourbon, hr. Andrzejowa Zamoyska ${ }^{126}$ na Spiżu w Lubowli ${ }^{127}$ mająca swe dobra. Jednakże hr. Szapary ${ }^{128}$ wyjechała do Włoch na kilka tygodni i w tym upatruję przerwę $\mathrm{w}$ dalszej pracy. Bo i sprawa objęcia świeckiego protektoratu uległa z tego powodu zwłoce i Najprz[ewielebniejszy] Ks. Biskup Csáky ${ }^{129}$ nie odpowiedział, o ile o tym mogę wiedzieć. Dlatego

\footnotetext{
${ }^{\mathrm{k}}$ Tekst pisany czarnym atramentem na 4 kartach czystego papieru formatu in folio. W górnej partii karty tytułowej nota niebieską kredką ręką archiwisty: „Danek”.

${ }^{124}$ Aluzja do Piusa X/Giuseppe Sarto (1935-1914), rzymskokatolickiego duchownego włoskiego, 1903-1914 papieża.

${ }^{125}$ Zob. aneks 6.

${ }^{126}$ Maria Carolina Giuseppina Ferdinanda Zamoyska z d. Bourbon (1856-1941) - córka księcia Franciszka Bourbon hrabiego Trapani oraz arcyksiężnej Marii Izabeli księżnej Toskanii. W 1885 r. poślubiła w Paryżu hr. Andrzeja Przemysława Zamoyskiego, syna Stanisława Kostki Andrzeja Zamoyskiego i Róży Marii Ewy Potockiej; mieli siedmioro dzieci. Źródło: Księżniczka Maria Karolina Burbon-Burbon (1856-1941) ...pl.qaz.wiki`wiki, Princess_Maria_Carolina_of_Bourbon [dostęp: 2 XI 2020].

${ }^{127}$ Lubowla - miasto we wschodniej Słowacji. Dobra te w 1883 r. nabyli Zamoyscy, które pozostawały w ich władaniu do końca II wojny światowej. Utracili je wskutek komunistycznej nacjonalizacji.

${ }^{128}$ Maria Alojza Szapary z d. Przeździecka (1874-1949) - córka Konstantego Przeździeckiego i Elżbiety Plater-Zyberk; w 1898 r. wyszła za mąż za Węgra Paula Szapáry de Muraszombath. Źródło: Maria Szapáry - Historical records and family trees - MyHeritage [dostęp: 2 XI 2020].

${ }^{129}$ Károly Emmanuel de Csáky (1852-1919) - węgierski duchowny rzymskokatolicki, święcenia kapłańskie w 1875 r., 1900-1919 biskup diecezji Vác na Węrzech. Zmarł 16 II 1919 r.
} 
upraszam pokornie Jego Ekscelencję, Najprzewielebniejszego Księdza Arcybiskupa, by raczył prywatnym swym listem zapewnić Najprz[ewielebniejszego] Ks. Biskupa hr. Csáky w Váca ${ }^{130}$ o tym, że Jego Ekscelencja objął duchowny protektorat oczekując oświadczenia się Najprz[ewielebniejszego] Ks. Biskupa hr. Csáky, jako współpatrona duchownego omawianego dzieła. Najprz[ewielebniejszy] Ks. Biskup hr. Csáky ceni Jego Ekscelencję bardzo wysoko, jak to $\mathrm{w}$ osobistej rozmowie przed rokiem poznałem i na list Jego Ekscelencji rychlej aniżeli na nasze starania odpowie, w pośpiechu prawdopodobnie pod tym względem zły stan zdrowia (ischias) Najprz[ewielebniejszemu] Ks. Biskupowi Wacowskiemu ${ }^{131}$ przeszkadza.

Najprz[ewielebniejszy] Ks. Biskup Várady ${ }^{132}$ ma najlepsze intencje. Jednakże żadna siła nie przeszkodzi zburzeniu starego kościółka na Kőbányi, skoro komisja inżyniersko-miejska postanowi go zdemolować. Dlatego idąc za radą Przew[ielebnego] Ks. Prałata Sapiehy ${ }^{133}$ proszę, aby Jego Ekscelencja, Najprzewielebniejszy Ksiądz Arcybiskup, raczył najłaskawiej wysłać list z prośbą do O. Gallen ${ }^{134}$, Benedyktyna w Emaus (w Pra$\mathrm{dze}^{135}$ ) o subwencję z Benifacius vereinu ${ }^{136}$ na nasz kościół w Budapeszcie a to $\mathrm{z}$ tych motywów, że kościółek ten będzie stał otworem dla misji niemieckich, tym bardziej, że misji tych od dawna tu nie urządzano. Owszem, nawet kazania niemieckie są usunięte z tutejszych kościołów mimo znacznej ilości zamieszkałych tu Niemców. Na żądanie

Źródło: Year 1919, Necrology [Catholic-Hierarchy], www.catholic-hierarchy.org/events/n1919.html [dostęp: 15 XI 2020].

${ }^{130}$ Diecezja Vác - jednostka administracyjna Kościoła rzymskokatolickiego na Węgrzech, erygowana w $1008 \mathrm{r}$.

${ }^{131}$ Alucja do biskupa diecezji Vác; poprawnie powinno być: vácskiemu.

${ }^{132}$ Lipót Árpád Várady (1865-1923) - syn Lajosa Várady i Leopoldiny Hassler, węgierski duchowny rzymskokatolicki, 1914-1923 arcybiskup Kalocsa. Źródło: Archidiecezja kalocsko-kecskemétska - Roman Catholic ...pl.qaz.wiki wiki> Roman_Catholic_Archdiocese_of [dostęp: 3 XI 2020].

${ }^{133}$ Adam Stefan Sapieha (1867-1951) - święcenia kapłańskie w 1893 r. we Lwowie, dr prawa kanonicznego, 1894-1895 wikariusz par. Jazłowiec, 1895-1897 studia specjalistyczne w Rzymie, 1897-1901 wicerektor Seminarium Duchownego we Lwowie, 1902-1911 kanonik Kapituły Metropolitalnej tamże, 1906-1911 sekretarz osobisty Piusa X w Rzymie; 24 XI 1911 prekonizowany biskupem krakowskim, 14 XII 1925 mianowany arcybiskupem, 18 II 1946 - kardynałem. Księga Sapieżyńska, red. J. Wolny, t. I-II, Kraków 1982-1986, passim; J. WoŁCZAŃSKI, Adam Stefan Sapieha w korespondencji z biskupami Galicji (Małopolski), [w:] Kardynat Adam Stefan Sapieha, red. S. Stępień, Przemyśl 1995, s. 94-99; Kardynat Adam Stefan Sapieha. Książę niezłomny, red. J. Urban, Kraków 2014, passim.

${ }^{134}$ Augustinus Wilhelm Emanuel von Gallen (1870-1949) - śluby zakonne złożył w Zakonie oo. Benedyktynów 1899 r., święcenia kapłańskie w 1901 r. w Emaus. Zmarł 2 IX 1949 r. we Fryburgu Szwajcarskim. Informacja pisemna o. Efrema Michalskiego OSB, Tyniec 18 XI 2020 r.

${ }^{135}$ Emaus - opactwo oo. Benedyktynów w Pradze (Czechy) założone zostało w $1347 \mathrm{r}$.

${ }^{136}$ Właściwie: Bonifacius-Verein - organizacja katolicka erygowana w 1849 r. w Ratyzbonie (Niemcy) celem wspierania katolików w diasporze. W szczególności wsparcie to obejmuje pomoc finansową przy budowie kościołów i innych budynków, a także przy budowie szkół, bibliotek, placówek oświatowych oraz zabezpieczenia środków transportu do nabożeństw. W $1853 \mathrm{r}$. wprowadzono je także w monarchii austro-węgierskiej. Szerzej zob. Der Bonifatius-Verein. Seine Geschichte, seine Arbeit und sein Arbeitsfeld 1849-1899, Paderborn 1899, passim. 
Jego Ekscelencji sam tę sprawę przedstawię Ojcu Gallen, proszę tylko pokornie o poparcie.

Łączę także prośbę usilną, by Jego Ekscelencja, Najprzewielebniejszy Ksiądz Arcybiskup raczył wysłać karty swoje wizytowe do dyrektorów następujących instytucji finansowych w kraju, do których podania o subwencje już wniosłem: do Banku Krajowego, do Towarzystwa Kredytowego Ziemskiego, do Banku Hipotecznego Galic[yjskiego], do Gal[icyjskiej] Kasy Oszczędności, do Towarzystwa Wzajemn[ych] Ubezpieczeń w Krakowie, a przynajmniej do niektórych z wymienionych instytucji.

Na ręce dra Głąbińskiego wniosłem też podanie do Sejmu, lecz podobno spóźnione. Nie chciałbym uszczuplać ofiarności na rzecz galic[yjskich] kościołów, ale korporacje te wspierają też demoralizujące teatry. Do magistratów Lwowa i Krakowa podania też wniosę.

Ufając odtąd jeszcze więcej duchowej pomocy i protektoratowi Jego Ekscelencji Najprzewielebniejszego Księdza Arcybiskupa, dziękuję najserdeczniej za ukazaną już pomoc oraz za łaskawe wsparcie materialne.

Z prawdziwą, najgłębszą czcią i poważaniem, oddany w Bogu sługa, oczekujący zleceń i informacji uprzejmych, dokąd zwrócić się jeszcze należy oraz przyobiecanego listu pasterskiego ${ }^{137} \mathrm{~J}[\mathrm{ego}]$ Ekscelencji wyglądam

Budapeszt X, Kelemen utca 32

Ks. Wincenty Danek

28 stycznia 1910

\section{Dokument 12}

$\dagger$

Jego ${ }^{1}$ Ekscelencjo, Najprzewielebniejszy Księże Arcybiskupie!

$\mathrm{Z}$ podziękowaniem za 2 ostatnie przesyłki listów pasterskich należy mi się spieszyć. Nie tak jak owe dwie starsze córki Lira ${ }^{138}$, muszę wyrazić, co czuję.

Listy pasterskie Jego Ekscelencji są tym dla mnie, czym są - wyobrażam to sobie dla dusz czyścowych modlitwy za nie. Tym większa należy się wdzięczność od obdarzonych Jego Ekscelencji.

Obszerny list wysłałem do Przew[ielebnego] O. Gallen w Pradze (Emaus). Proszę tylko, by Jego Ekscelencja, Najprzewielebniejszy Ksiądz Arcybiskup, raczył sprawę tę poprzeć najłaskawiej. Proszę także, by Jego Ekscelencja, Najprzewielebniejszy Ksiądz Arcypasterz raczył wzmiankę uczynić w „Kurendzie”139 o błogosławieństwie Apostol-

${ }^{137}$ Prawdopodobnie: J. BILCZEWSKI, List pasterski w pięćsetna rocznice bł. Jakuba Strepy, Lwów 1909; TENŻE, Życie święte, święta śmierć. List pasterski do kapłanów i wiernych, Lwów1910.

${ }^{1}$ Tekst pisany czarnym atramentem na 3,5 kartach czystego papieru formatu in folio. W górnej partii karty tytułowej nota niebieską kredką ręką archiwisty: „Danek”.

${ }^{138}$ Właściwie: Leara. Nawiązanie do tytułowych bohaterów tragedii Williama Shakespeare'a Król Lear: króla Brytanii Leara i jego córek Goneril, Regan i Kordelii. Dwie starsze umiały wyrazić swoją miłość ojcu, najmłodsza nie potrafiła tego uczynić.

139 „Kurenda Konsystorza Metropolitalnego obrządku łacińskiego” - pismo urzędowe Kurii 
skim Ojca Św[iętego] udzielonym tym, co odnośnie do budowy kościoła polskiego w Budapeszcie zamierzonej, według słów Ojca Św[iętego], własną Jego ręką kreślonych, „miłują ozdobę domu Bożego i miejsce mieszkania Jego na ziemi”. Załączam prośbę o przesyłkę 1 egzemplarza tej „Kurendy”"140. Pragnę fotoligrafowane błogosławieństwo to rozesłać (większym) urzędom parafialnym we większych miastach z prośbą o afigowanie ${ }^{141}$ facsimila tegoż błogosławieństwa za osłoną z celiloidy przeźroczystej na wewnętrznych drzwiach kościelnych przez jedną niedzielę ${ }^{142}$, gdzie by przy ewentualnej staży pań kwestorek ludność także uboga własnoręczne pismo Ojca Św[iętego] wraz z thumaczeniem tego pisma na język polski (i węgierski) oglądać mogła. Przew[ielebnych] Księży Proboszczów uproszę, by jednej niedzieli o rzeczy całej wzmiankę uczynili w kazaniu i jedną ze zwykłych (kwest) składek niedzielnych na ten cel przeznaczyli.

Do tego jednak potrzeba mnie przede wszystkim pozwolenia Jego Ekscelencji, Najprzewielebniejszego Księdza Arcybiskupa, na które radbym się powołać w cyrkularzu wysłanym do Przew[ielebnych] Księży Proboszczów, o ile i na ten szczegół otrzymam pozwolenie najwyższej w kraju władzy duchowej Jego Ekscelencji, o które pokornie proszę.

Ośmielam się także poruszyć tu tę kwestię. Uważałem na Węgrzech zdaje się więcej przyczyniać, aniżeli kazania nieomal ku pomnożeniu czci Świętych rozszerzenie obrazów skioptikowanych ${ }^{143} \mathrm{w}$ tych czasach, kiedy to po miastach zwłaszcza tak rozogniona żądza zabawy, a zmniejszona ochota przebywania dłuższy czas w kościele. Tak na przykład tu rozpowszechnia jeden z ks[ięży] katechetów, obecnie wikary, ks. dr Krizs ${ }^{144}$ szereg obrazów z życia Św. Jadwigi ${ }^{145}$ (Elźbiety ${ }^{146}$ ).

Ośmielam się prosić, aby Jego Ekscelencja, Najprzewielebniejszy Ksiądz Arcybiskup, raczył przy okazji zachęcić artystów polskich do przedstawienia obrazowego

Metropolitalnej ob. łac. we Lwowie ukazujące się w latach 1834-1939. Publikowano tam akta Stolicy Apostolskiej, Kurii Metropolitalnej i arcybiskupa lwowskiego, listy pasterskie rządców lokalnego Kościoła, rozporządzenia władz cywilnych i in. Bibliografia katolickich czasopism religijnych $w$ Polsce 1918-1944, oprac. i red. Z. Zieliński, Lublin 1981, s. 66-67.

140 Petycja ks. Danka nie została zrealizowana w 1910 r. Dopiero w następnym roku, w „Kurendzie” nr 6 ukazał się apel do proboszczów archidiecezji lwowskiej o przeznaczenie „choć jednej ze składek niedzielnych" na budowę kościoła polskiego w Budapeszcie. [Nota w sprawie finansowego wsparcia budowy kościoła polskiego w Budapeszcie], „Kurenda Konsystorza Metropolitalnego obrządku łacińskiego" 1911, nr 6, s. 71-72.

${ }^{141} \mathrm{Z}$ łac.: afigo, ere - umocować, przybić, przyłączyć.

${ }^{142}$ Sens zdania: umieszczenie facsimile tekstu błogosławieństwa w oprawie celuloidowej na drzwiach kościelnych.

${ }^{143}$ Skioptikon - projektor do przezroczystych obrazów; prekursor współczesnego rzutnika slajdów.

${ }^{144}$ Osoba niezidentyfikowana.

145 Św. Jadwiga Śląska (ok. 1180-1243) - Niemka, córka Bertolda VI von Andechs i Agnieszki von Rochlitz, siostra Getrudy - żony króla węgierskiego Andrzeja II i matka św. Elżbiety Węgierskiej, święta Kościoła katolickiego.

146 Św. Elżbieta Węgierska (1202-1231) - córka króla Węgier Andrzeja II i Gertrudy z Meran, franciszkańska tercjarka, święta Kościoła katolickiego. 
szczegółów z życia Świętych patronów naszych polsk[ich] np. Bł. Kingi ${ }^{147}$, patronki polskiej i węgierskiej oraz patronki przyszłego kościoła polsk[iego] w Budapeszcie ${ }^{148}$, co by dopomogło do sporządzenia diapozytyw skioptikonowych. Zwrócę się z tym do Najprz[ewielebniejszego] Księdza Biskupa Bandurskiego ${ }^{149}$, który zapewne ma znajomości w gronie artystów krakowskich. Lecz powaga Jego Ekscelencji Najprzewielebniejszego Księdza Arcybiskupa i nieoceniona dla nas protekcja oraz życzliwość dla sprawy każą mnie więcej przywiązywać nadziei do interwencji J[ego] E[kscelencji] Najprzewiel[ebniejszego] Księdza Arcybiskupa, o którą usilnie proszę z uwagi na możliwe korzyści duchowe i materialne także pośród Węgrów.

Upraszam w końcu o łaskawe polecenie poinformowania mnie, czyli zgłaszającego się ks. Chwojki ${ }^{150}$ można użyć do chwilowej pomocy w słuchaniu spowiedzi wielkanocnej.

Pozostaję z najgłębszą czcią i poważaniem - wdzięczny i oddany sługa

Budapeszt X, Kelemen u[tca] 32

$$
\text { Ks. Wincenty Danek }
$$

9 lutego 1910

${ }^{147}$ Św. Kinga (1234-1292) - córka Beli IV króla Węgier i Marii Laskariny, żona polskiego księcia Bolesława V Wstydliwego, zakonnica w Zakonie ss. Klarysek, święta Kościoła katolickiego.

148 Świątynia ta otrzymała wezwanie Najświętszej Maryi Panny Wspomożycielki Wiernych.

149 Władysław Bandurski (1865-1932) - święcenia kapłańskie w 1887 r. we Lwowie, dr teologii, 1889-1893 wikariusz par. Kamionka Strumiłowa, 1893-1895 wikariusz w katedrze lwowskiej, 1895-1896 sekretarz bp. Jana Puzyny w Krakowie, 1896-1906 kanclerz Kurii Biskupiej tamże, od 1899 r. kanonik Kapituły Katedralnej na Wawelu. 26 IX 1906 prekonizowany biskupem pomocniczym archidiec. lwowskiej: wikariusz generalny i rektor Seminarium Duchownego, działacz patriotyczno-społeczny. Po wybuchu I wojny światowej udał się do Krakowa, a stamtąd do Wiednia. Wskutek oskarżeń o nadużycia natury moralnej został zmuszony przez episkopat rzymskokatolicki Galicji do rezygnacji z funkcji biskupa pomocniczego, 16 IV 1917 otrzymał stosowny dekret Stolicy Apostolskiej. Po 1918 r. osiadł w Wilnie; był duszpasterzem Legionów, generałem dywizji, autorem licznych publikacji religijno-patriotycznych. AALK, bsygn., J. Bilczewski, Dziennik, Lwów 1900-1923, passim; AALK, bsygn., Kopia pisma abp. J. Bilczewskiego do ministra Ludwika Ćwiklińskiego, Lwów 29 III 1918 r., teczka: Korespondencja abp. J. Bilczewskiego; S. RACHWAE, Ks. biskup dr Władysław Bandurski. Wzór kapłana-Polaka, Lwów 1913, passim; W.J. WYsOCKI, A.C. ŻAK, Biskup Władystaw Bandurski, Pruszków 1997, passim.

${ }^{150}$ Dominik Chwojka (1871-1951) - święcenia kapłańskie w 1897 r. we Lwowie, 1897-1898 wikariusz par. Tłumacz, 1898-1899 wikariusz par. Kamionka Strumiłowa, 1899-1900 wikariusz par. Jagielnica, 1900-1902 wikariusz par. Bobulińce, 1902-1903 wikariusz par. Horodenka, 1903-1904 wikariusz par. Świrz, 1904-1906 wikariusz par. Konkolniki, 1906-1911 rezydent w Petlikowcach, Bielanach k. Krakowa i Wiedniu, 1911-1915 katecheta par. Kałusz, 1915-1918? kapelan wojskowy, 1918?-1924? katecheta szkoły powszechnej w Kulikowie, 1924?-1926 katecheta szkoły powszechnej w Zaborowie, 1926-1930 katecheta szkoły powszechnej w Bóbrce, 1930-1932 administrator par. Podhajczyki Justynowe, 1932-1944 emeryt w par. Trembowla. W 1945 r., w ramach ekspatriacji, wyjechał do diec. katowickiej, ale nie dostał tam angażu, 1946-1950 administrator par. Pikulice - diec. przemyska, 1950-1951 kapelan domu ss. Albertynek w Przemyślu przy ul. Mariackiej. Zmarł 1 IV 1951 r. w Przemyślu. J. WoŁCZAŃSKI, Eksterminacja narodu polskiego..., cz. 1, s. 452; informacje własne. 


\section{Dokument 13}

Jego $^{\uparrow}$ Ekscelencjo, Najprzewielebniejszy Księże Arcybiskupie!

Jako duchowe wiązanie ${ }^{151}$ w dzień Imienin Jego Ekscelencji Najprzewielebniejszego Księdza Arcybiskupa, ośmielam się przesłać Jego Ekscelencji wiadomość, że Najprz[ewielebniejszy] Ks. Biskup sufragan Kohl ${ }^{152}$, alter ego ${ }^{153} \mathrm{~J}$ [ego] Em[inencji] Ks. Kardynała Vaszary ${ }^{154}$, polecił mnie na piśmie przedłożyć prośbę o przyjęcie protektoratu przez J[ego] Em[inencję] Ks. Kardynała nad dziełem budowy kościoła polsk[iego] w Budapeszcie, czyniąc nadzieję pomyślnego załatwienia. $\mathrm{Z}$ tą wiadomością łączę szczere życzenia dla Jego Ekscelencji i podziękowania najserdeczniejsze za dotychczasowe trudy i cierpliwość w wysłuchiwaniu licznych próśb moich.

J[ego] E[kscelencję] Marszałka kraju, hr. Badeniego, prosiłem o zalecenie dzieła (wzgl[ędnie] pomocy materialnej) radom powiatowym. Dotychczas 2 Rady powiatowe (jeszcze przed wysłaniem tej prośby do marszałka) nadesłały subwencje. Dlatego o najłaskawsze poparcie tej mojej prośby we formie okólnika wysłanego do rad powiatowych przez marszałka pozwalam sobie prosić Jego Ekscelencję najpokorniej.

Pozostaję z najgłębszą czcią, poważaniem i wdzięcznością, oddany sługa

Budapeszt, X Kelemen u[tca] 32

$$
\text { Ks. W[incenty] Danek }
$$

17.3.1910

\section{Dokument 14}

$\mathrm{Jego}^{\mathrm{m}}$ Ekscelencjo, Najprzewielebniejszy Księże Arcybiskupie!

Znowu pozwalam sobie udać się w opiekę Jego Ekscelencji, Najprzewielebniejszego Księdza Arcybiskupa, za radą Ojca Weisera.

\footnotetext{
${ }^{\mathfrak{}}$ Tekst pisany czarnym atramentem na 1,5 kartki czystego papieru formatu in folio. W górnej partii karty tytułowej nota niebieską kredką ręką archiwisty: „Danek”.

151 Przestarzałe: życzenia.

152 Jozsef Medard Kohl (1859-1928) - węgierski duchowny rzymskokatolicki, święcenia kapłańskie w 1885 r. w Zakonie oo. Benedyktynów, 1900-1928 biskup pomocniczy archidiecezji Esztergom. Zmarł 15 I 1928 r. Źródło: Bishop Jozsef Medard Kohl [Catholic-Hierarchy], www. catholic-hierarchy.org/bishop/bkohl.html [dostęp: 12 XI 2020].

${ }^{153}$ Łac.: osoba pokrewna komuś pod względem duchowym.

${ }^{154}$ Kolos Ferenc Vaszary (1832-1915) - węgierski duchowny katolicki, święcenia kapłańskie w 1856 r. w Zakonie oo. Benedyktynów, 1891-1912 arcybiskup Ostrzyhomia i prymas Węgier, od 1893 r. kardynał; 1913-1915 rezydował w Balatonfüred po rezygnacji z pełnionych urzędów. Źródło: Kolos Ferenc Vaszary - Wikipedia, wolna encyklopedia pl.wikipedia.org〉wiki> Kolos Ferenc_Vaszary [dostęp: 3 XI 2020].

$\mathrm{m}$ Tekst pisany czarnym atramentem na 2,5 kartki czystego papieru formatu in folio. W górnej partii karty tytułowej nota niebieską kredką ręką archiwisty: „Danek”.
} 
Siostry Karmelitanki w Nowym Peszcie poszukują kapelana. Zgłosił się ks. Kruczek $^{155}$, emerytowany proboszcz z Poraża (p[oczta] Zagórz ${ }^{156}$ ) z diecezji przemyskiej. Siostry ofiarują tylko 30 złr miesięcznie i śniadanie, nawet mieszkania kapelanowi nie chcą zapewnić. Proszę tedy pokornie a usilnie w interesie tych wielu Polaków mieszkających w Nowym Peszcie, dla których tylko raz w miesiącu w pobliżu sióstr Karmelitanek odprawiam nabożeństwo, aby Jego Ekscelencja, Najprz[ewielebniejszy] Ksiądz Arcybiskup raczył skreślić kilka słów do J[ego] E[kscelencji] Najp[rzewielebniejszego] Ks. Biskupa hr. Csáky w Wacowie, do którego Nowy Peszt należy, aby tenże Najp[rzewielebniejszy] Ks. Biskup raczył uprosić hrabiego Károlyi ${ }^{157}$, dobrego katolika, mającego duże posiadłości tuż obok Pesztu, ku odstąpieniu części w licznych obok znajdujących się domostwach swoich na mieszkanie dla kapelana zakonnic, albo by Najprz[ewielebniejszy] Ks. Biskup Csáky w inny sposób, o ile by domostwa te nie dały się na ten cel użyć bądź z powodu oddalenia (o czym dokładnie nie wiem), bądź z innych przyczyn, raczył dopomóc tak tym zakonnicom, posiadającym ochronkę, jak również Polakom Nowo-Pesztańskim ich pastorację ${ }^{158}$ wprowadzając na właściwsze tory.

Na razie o protektoracie Najprz[ewielebniejszemu] Ks. Biskupowi hr. Csáky nic nie wspominam, bo i hrabina Szapary przygnębiona chorobą syna we Włoszech zawzięcie milczy, a z drugiej strony, uczyniono mnie małą nadzieję, że po upływie 10 dni mogę się starać o protektorat J[ego] Em[inencji] Ks. Prymasa Vaszary.

Mimo to i obok tego ożywia mnie nadzieja thumaczenia bądź podręcznika Adoracji Przen[ajświętszego] Sakramentu ${ }^{159}$, bądź listu pasterskiego Jego Ekscelencji o Przen[ajświętszym] Sakramencie ${ }^{160} \mathrm{z}$ języka niemieckiego na węgierski, której to transwersji ${ }^{161}$ ma dokonać pewien kapłan tutejszy. Dlatego upraszam ponownie o łaskawą przesyłkę niemieckich egzemplarzy tych prac, o co prosiłem Przew[ielebnego] Ks. Kan[onika] Puchalskiego ${ }^{162}$.

${ }^{155}$ Marcin Kruczek (1852-1941) - święcenia kapłańskie w 1876 r. w Przemyślu, proboszcz par. Poraż, 1931-1939 emeryt-rezydent we Lwowie. Zmarł 20 VII 1941 r. Schematismus archidioecesis Leopoliensis ritus latini 1932-1939, Leopoli 1932-1939, passim; informacja ks. dr. Marcina Kapłona, Przemyśl 14 XI 2020 r.

${ }^{156}$ Zagórz - miejscowość w pow. Sanok, woj. Lwów.

${ }^{157}$ Mihály Ádám György Miklós Károlyi de Nagykároly (1875-1955) - Węgier, katolik, arystokrata, 1905-1906 i 1910-1914 członek parlamentu węgierskiego, w 1916 r. założył i przewodniczył Zjednoczonej Partii Niepodległości, 1918-1919 premier i prezydent Węgierskiej Republiki Ludowej, w 1919 r. udał się na emigrację najpierw do Austrii, Czechosłowacji, Jugosławii, a potem do Anglii i Francji; na Węgry wrócił w 1946 r., pełniąc funkcję ambasadora w Paryżu (1947-1949), po rezygnacji z tej misji pozostał do śmierci we Francji. Źródło: Mihály Károlyi Wikipedia, wolna encyklopedia, pl.wikipedia.org〉wiki〉Mihály_Károlyi [dostęp: 3 XI 2020].

${ }^{158}$ Opiekę duszpasterską.

159 [W. PUCHALSKI], Podręcznik adoracji Najświętszego Sakramentu ułożony z polecenia Najprzew[ielebniejszego] Arcybiskupa Metropolity Lwowskiego, Lwów 1902, ss. 302.

${ }^{160}$ J. BiLCZEwSKI, Chleb żywota. List pasterski do kapłanów i wiernych, Lwów 1910.

${ }^{161}$ Przestarzałe: tłumaczenia, przekładu.

${ }^{162}$ Wawrzyniec Puchalski (1842-1920) - święcenia kapłańskie w 1867 r. w Przemyślu, wikariusz w Sanoku i Samborze, 1874-1875 proboszcz par. Wysoka k. Łańcuta, 1875-1893 proboszcz par. Łąka, 1893-1920 proboszcz par. Wyżniany - archidiec. lwowska, od 1901 r. zarządca dóbr 
Pozostaję z najgłębszą czcią, poważaniem i wdzięcznością - oddany, Opatrzności Bożej i zabiegliwości Jego Ekscelencji Najprzewielebniejszego Księdza Arcybiskupa polecający tę sprawę, sługa

Budapeszt, X Kelemen utca 32

Ks. Wincenty Danek

10 III 1910

\section{Dokument 15}

$\mathrm{Jego}^{\mathrm{n}}$ Ekscelencjo, Najprzewielebniejszy Księże Arcybiskupie!

Serdecznie dziękuję Jego Ekscelencji Najprzewielebniejszemu Księdzu Arcybiskupowi, za list najłaskawszy, życzliwość i życzenia.

W święta byłem sam - ks. Dziurzyński ${ }^{163}$ się rozchorował, wiele też z tego powodu miałem przykrości, co bardziej bolesne, niż trud i praca.

Pensję wypłaca mnie tutejsze ministerstwo oświaty z funduszu religijnego (1[iczba] rezolucji: 108.029/908) z tym tylko niepojętym dla mnie dostatecznie zastrzeżeniem tut[ejszego] Najprz[ewielebniejszego] Konsystorza, że kwartalne, ostemplowane kwity posyłać jestem obowiązany do kancelarii Konsystorskiej, stąd też płacę pośrednio otrzymuję. Najprz[ewielebniejszy] zaś Konsystorz roczne składa sprawozdanie z użycia kwoty na ten cel przeznaczonej powagą ministerstwa, jak to wynika z treści komunikatu Kancelarii Konsystorskiej z 14 października 1908 [r.]. Podobnie też objaśniono mnie przy pewnej sposobności w ministerstwie oświaty, z czego wnioskuję, że Najprz[ewielebniejsi] Księża Biskupi węgierscy do mojego utrzymania się nie przyczyniają.

Dlatego znowu powolny wskazówkom O. Weizera [sic!] TJ ośmielam się prosić Jego Ekscelencję, Najprzewielebniejszego Księdza Arcybiskupa, o łaskawe wdrożenie kroków ku zapewnieniu wydatniejszej opieki duchownej dla Polaków w Budapeszcie, może za pośrednictwem podeszłego już, lecz krzepkiego hr. Zichy ${ }^{164}$, wodza katolików węgierskich (w Budapeszcie, VIII Scitovszky - tér).

stołowych arcybiskupstwa lwowskiego, szambelan papieski, autor zbiorów kazań i czytań różańcowych dla ludu oraz kilku monografii parafii. Zmarł 15 III 1920 r. na tyfus. Kościół rzymskokatolicki i Polacy w Małopolsce Wschodniej podczas wojny ukraińsko-polskiej 1918-1919. Źródła, t. I, oprac., wstęp, przypisy, indeksy i wybór fotografii J. Wołczański, Lwów-Kraków 2012, s. 591.

${ }^{\mathrm{n}}$ Tekst pisany czarnym atramentem na 2,5 kartki czystego papieru formatu in folio. W górnej partii karty tytułowej nota niebieską kredką ręką archiwisty: „Danek”.

${ }^{163}$ Kazimierz Dziurzyński (1872-1951) - święcenia kapłańskie w 1896 r. we Lwowie, 1916-1946 kanonik gremialny Kapituły Metropolitalnej we Lwowie, proboszcz Bazyliki Metropolitalnej tamże, dziekan dekanatu Lwów-miasto, odznaczony Złotym Krzyżem Zasługi (przed 1939 r.); w ramach ekspatriacji wyjechał w 1946 r. do Przemyśla, 1946-1951 rezydent tamże. Zmarł 17 III 1951 r. w Przemyślu. Schematismus [...] 1896-1939, Leopoli 1896-1939, passim; AJWK, bsygn., Spis duchowieństwa, s. 136.

164 János Mária Baptista Ferdinánd Szilveszter György Henrik Aladár Kamilló Zichy (1868-1944) - węgierski arystokrata, prawnik i polityk katolicki, dr prawa, 1896-1918 członek Zgromadzenia Parlamentarnego, długoletni przewodniczący do 1903 r. Katolickiej Partii Ludowej, od 
O. Weizer [sic!] sądzi, że gdyby jaki ksiądz młody, mający zdolności do języków mógł być przyjęty do tutejszej diecezji, to łatwiej by można potrzebie zaradzić, boć sam jeden dla 15000, według innej wersji dla 25000 dusz, nie mogę podołać - zwłaszcza wobec rozproszenia Polaków w rozległych dzielnicach Pesztu.

Co do mnie, prosiłbym przynajmniej Jego Ekscelencję, Najprzewielebniejszego Księdza Arcybiskupa, o łaskawe skreślenie listu albo wprost do hr. Károlyi, Ujpest József utca 26, albo za pośrednictwem J[ego] E[kscelencji] Ks. Biskupa hr. Csáky w Wacowie, w celu zabezpieczenia stałego mieszkania dla ks. Kruczka, em[erytowanego] proboszcza z Poraża ${ }^{165}$ ad Zagórz z diecezji przemyskiej, który w takim razie miałby objąć kapelanię u (biednych) ubogich sióstr Karmelitanek w Nowym Peszcie.

Hr. Władysław Károlyi ${ }^{166}$ podobno jeszcze nie wrócił z Biaritz ${ }^{167}$. Wkrótce mają się tu odbyć misje w tych dzielnicach, w których ćwiczeń duchownych od dawna nie było, a to pod kierunkiem jedynego (obcego) pracownika: O. Ziemby ${ }^{168}$, Zmartwychwstańca, przebywającego obecnie w Rzymie.

Łączę wyrazy najgłębszej czci, poważania i wdzięczności, oddany w Bogu sługa

W Budapeszcie, X Kelemen utca 32

Ks. Wincenty Danek

30 marca 1910

1906 r. należał do Krajowej Partii Konstytucyjnej, a po jej rozwiązaniu - do Narodowej Partii Pracy, 1910-1913 i 1918 minister edukacji religijnej i publicznej Królestwa Węgier, w 1919 r. zgłosił akces do Komitetu Antybolszewickiego w Wiedniu, w 1922 r. założył Krajowe Towarzystwo Legitymistyczne, przekształcone później w Chrześcijańską Partię Gospodarczą i Społeczną, od 1925 r. był członkiem Węgierskiej Akademii Nauk i kawalerem Orderu Złotego Runa. Zmarł w 1944 r. Źródło: János Zichy, hr. Zisci: Myśl Konserwatywna, myslkonserwatywna.pl>janoszichy-hr-zisc [dostęp: 3 XI 2020].

${ }^{165}$ Poraż - wieś w pow. Lesko, woj. Lwów.

166 Osoba niezidentyfikowana.

${ }^{167}$ Biaritz - popularna miejscowość turystyczna we Francji, departament Pireneje Atlantyckie.

168 Józef Ziemba (1871-1938) - święcenia kapłańskie w Zgromadzeniu Księży Zmartwychwstańców w 1896 we Lwowie, 1896-1897 wicerektor internatu w Krakowie, 1897-1906 duszpasterz i misjonarz w polskich parafiach w USA: 1897-1905 duszpasterz par. pw. św. Stanisława Kostki w Chicago, w 1902 r. proboszcz par. pw. św. Stanisława Biskupa w Fall River i w 1906 r. analogicznie par. pw. Matki Bożej Anielskiej w Chicago; 1906-1912 rekolekcjonista i misjonarz z siedzibą w Krakowie, skąd dojeżdżał z rekolekcjami m.in. do Polaków na Węgrzech, Bukowinie i w Saksonii, 1906-1907 katecheta szkoły ludowej im. T. Kościuszki w Krakowie, 1912-1916 misjonarz wśród Polonii w Bośni, 1916-1917 wikariusz par. Zawoja, 1919-1923 duszpasterz par. pw. Najświętszego Zbawiciela w Warszawie, 1923-1934 pracował w USA jako członek grupy misyjnej i ojciec duchowny przy zakonnym Seminarium Duchownym św. Jana Kantego w St. Louis, 1934-1938 rezydent w Krakowie. Zmarł 3 I 1938 r. tamże. Informacja pisemna ks. Macieja Gawlika CR, Kraków 5 XI 2020 r. 


\section{Dokument 16}

$\mathrm{Jego}^{\circ}$ Ekscelencjo, Najprzewielebniejszy Księże Arcybiskupie!

Powołując się na załączoną odpowiedź Dyrekcji Gal[icyjskiego] Towarzystwa Kredytowego Ziemskiego przesłaną komitetowi w załatwieniu prośby o zapomogę na budowę kościoła polskiego w Budapeszcie, podpisany ośmiela się pokornie prosić Jego Ekscelencję, Najprzewielebniejszego Księdza Arcybiskupa o łaskawe wyasygnowanie subwencji na tę budowę ze wzmiankowanego w załączonym piśmie funduszu.

Subwencja ta $\mathrm{w}$ tej chwili tym bardziej jest pożądana, ile że komitet otrzymał błędne zawiadomienie z dyrekcji pocztowej kasy oszczędności w Budapeszcie tej treści, że na otwarte już konto czekowe (węgierskie) nadeszła kwota 6000 koron, o czym podpisany ludowi - dla zachęty - bezwłocznie z ambony ogłosił. Gdy z czasem wykazało się, że przy olbrzymim ruchu czekowym błędne zawiadomienia są na porządku dziennym, podpisany doznał zawodu. Niemal niepodobna bowiem odwoływać ogłoszenia publicznego bez ściągania na komitet podejrzenia u ludzi niewykształconych, nie rozumiejących obrotu czekowego, tym bardziej, że kontrola tutejszego Najprzewielebniejszego Ordynariatu dla pewnych formalności urzędowych nie jest jeszcze zarządzona, jak o to komitet prosił. Dotychczas uzbierano 950 koron.

$\mathrm{Z}$ najgłębszą czcią i poważaniem oddany sługa (za komitet)

ks. Wincenty Danek

W Budapeszcie X, Kelemen u[tca] 32

5 kwietnia 1910

\section{Dokument 17}

Jego $^{p}$ Ekscelencjo, Najprzewielebniejszy Księże Arcybiskupie!

Przy silnym ruchu przedwyborczym (do parlamentu węgierskiego), w którym także obecny minister oświaty hr[abia] Zichy udział bierze, konieczną będzie silna agitacja,

${ }^{\circ}$ Tekst pisany czarnym atramentem na 2,5 kartki czystego papieru formatu in folio. W górnej partii karty tytułowej nota niebieską kredką ręką archiwisty: „Danek”. U dołu trzeciej karty widnieje owalna pieczęć z napisem: „Lengyel Templom Epitési Bizottság Budapest”. Do tegoż dokumentu dołączono pismo Galicyjskiego Towarzystwa Kredytowego Ziemskiego ze Lwowa sporządzone na maszynie z nieczytelnymi dwoma autografami: „Galicyjskie Towarzystwo Kredytowe Ziemskie, Lwów, dnia 25 marca.1910, L. 1562. (Prośba komitetu bud[owy] kościoła pol[skiego] w Budapeszcie). Do Szanownego Komitetu budowy kościoła polskiego w Budapeszcie. Na cenne pismo z prośbą z dnie 21 stycznia br. mamy zaszczyt oznajmić, że tegoroczne Ogólne Zgromadzenie Delegatów Gal[icyjskiego] Towarzystwa kredytowego ziemskiego, uchwaliło wypłacić subwencję na budowę kościołów i kaplic do rąk J[ego] E[kscelencji] Ks. Arcybiskupa Bilczewskiego, który rozdziela ją według swego uznania. Dyrekcja Gal[icyjskiego] Towarzystwa kredytowego ziemskiego nie posiada na te i tym podobne cele żadnych innych funduszów. Z Dyrekcji Gal[icyjskiego] Towarzystwa Kred[ytowego] Ziemsk[iego]. Dyrektor [...]”.

$\mathrm{p}$ Tekst pisany czarnym atramentem na 2 kartkach czystego papieru formatu in folio. W górnej partii karty tytułowej nota niebieską kredką ręką archiwisty: „Danek”. 
aby w tymże ministerstwie odwrócono uwagę od tej walki na zajęcie się chwilowe sprawą subwencji na nasz kościół w Budapeszcie, w czym od pierwszej chwili nie pozbawiono mnie nadziei pomyślnego rezultatu.

$Z$ drugiej strony w drugim półroczu fundusz odnośny w tymże ministerstwie prawdopodobnie będzie wyczerpany. Dlatego spiesząc się w tej sprawie, proszę najpokorniej, aby Jego Ekscelencja, Najprzewielebniejszy Ksiądz Arcybiskup wraz z J[ego] E[kscelencją] N[a]j[przewielebniejszym] Ks[iędzem] Biskupem Pelczarem raczyli w Rzymie poczynić przedsięwzięte starania celem jakiegokolwiek odznaczenia Najprz[ewielebniejszego] Ks[iędza] Biskupa tyt[ularnego] dra Leopolda Arpoda Várady, szefa sekcji w tutejszym ministerstwie oświaty, który przy kreowaniu posady kapelana dla Polaków już się zasłużył akcją swoją, a w przyszłości może także być pomocnym przy wyznaczaniu subwencji na wiekopomne dzieło, tj. na kościół polski na obczyźnie w Budapeszcie. Wieść o zamierzonym odznaczeniu zachęci N[a]j[przewielebniejszego] Ks[iędza] Biskupa Várady. Tej myśli odznaczenia N[a]j[przewielebniejszego] Ks[iędza] Biskupa Várady był także ks. dr Kantak ${ }^{169}$, który mnie tu odwiedził; tym chętniej tedy ją wyjawić się ośmielam.

Pozostając z najgłębszą czcią i wdzięcznością - Jego Ekscelencji oddanym sługą

Budapeszt, X Kelemen u[tca] 32

Ks. Wincenty Danek

7 IV 1910

\section{Dokument 18}

Jego $^{\mathrm{r}}$ Ekscelencjo, Najprzewielebniejszy Księże Arcybiskupie!

Ośmielam się donieść Jego Ekscelencji, Najprzewielebniejszemu Księdzu Arcybis-

169 Kamil Kantak (1881-1976) - święcenia kapłańskie w 1904 r. w Poznaniu, dr teologii, 1909-1910 podróżował po Europie, 1910-1919 duszpasterz i archiwariusz w Poznaniu, do 1914 r. redaktor „Miesięcznika Kościelnego Unitas”, w 1919 r. uzyskał habilitację w Pradze, 1919-1922 wykładowca Seminarium Duchownego w Poznaniu, 1922-1923 przebywał na Pomorzu, 1923-1926 rektor kościoła pw. św. Jacka w Warszawie, 1926-1939 wykładowca Seminarium Duchownego w Pińsku; po wybuchu II wojny światowej został aresztowany przez NKWD i osadzony w różnych obozach sowieckich, później trafił do Wojska Polskiego gen. W. Andersa w ZSRR jako kapelan, wraz z oddziałami wojskowymi i Polakami cywilnymi dotarł w 1943 r. do Bejrutu: 1943-1946 wykładowca w miejscowym Seminarium Duchownym, 1947-1948 analogicznie w tamtejszym Uniwersytecie Catholique Française, w Bejrucie pozostał do końca życia wykładając na Uniwersytecie Katolickim św. Józefa i pełniąc funkcję kapelana ss. Szarytek jerozolimskich; był autorem kilkuset prac z dziedziny historii, literatury i polityki. Zmarł 1 XII 1976 r. w Bejrucie. A. BEDNAREK, Kantak Kamil, [w:] Encyklopedia Katolicka, t. VIII, red. zbior., Lublin 2000, kol. 623-624 (biogram niepełny); J. JACHOWSKI, Kantak Kamil, [w:] Wielkopolski stownik biograficzny, red. A. Gąsiorowski, J. Topolski, Warszawa-Poznań 1981, s. 313; H.E. WycZAwSKI, Kantak Kamil Juliusz, [w:] Stownik polskich teologów katolickich, t. VI, red. L. Grzebień, Warszawa 1983, s. 30-41.

${ }^{\mathrm{r}}$ Tekst pisany czarnym atramentem na 3 kartkach czystego papieru formatu in folio. W górnej partii karty tytułowej nota niebieską kredką ręką archiwisty: „Danek”. 
kupowi, o równoczesnemu wysłaniu listu wraz z petycją o subwencję na rzecz kościoła polskiego w Budapeszcie, którą to prośbę przedłożyłem radzie miasta Lwowa na ręce prezydenta Ciuchcińskiego ${ }^{170}$. Pozwalam sobie prosić Jego Ekscelencję, Najprzewielebniejszego Księdza Arcybiskupa, o łaskawe poparcie. Ponadto równocześnie i w tym także, co poniżej, posłusznym będąc wskazówkom o. Weizera [sic!] TJ proszę, by Jego Ekscelencja, Najprzewielebniejszy Ksiądz Arcybiskup, raczył poczynić kroki, względnie dopomóc w sprawie odznaczenia papieskiego dla Ks. Biskupa dra Várady, szefa sekcji w węgier[skim] ministerstwie oświaty. Ks. Biskup Majlath ${ }^{171}$ z Siedmiogrodu ${ }^{172}$ (z Gyula Féhervár ${ }^{173}$ ) zapytany przeze mnie, jakie odznaczenie dla ks. Biskupa Várady byłoby możliwe, życzliwie odpisał mi na kartce, że sprawę tę oddał właściwemu Ordynariuszowi w Temeszvarze ${ }^{174}$ - Ks. Biskupowi dr. Csernochowi ${ }^{175}$ (Temeszvar). Proszę przeto, by J[ego] E[kscelencja], Najprzewielebniejszy Ksiądz Arcybiskup albo w Rzymie, albo w Ordynariacie Temeszvarskim, albo za pośrednictwem serdecznego przyjaciela Ks. Biskupa Várady, tj. u Ks. Biskupa dra Augusta Fischera-Colbrie ${ }^{176}$, Ordynariusza w Ka-

${ }^{170}$ Stanisław Ciuchciński (1841-1912) - uczestnik Powstania Styczniowego, z zawodu blacharz, 1883-1912 radny miasta Lwowa, 1899-1907 wiceprezydent Lwowa, 1907-1911 prezydent miasta, 1907-1912 poseł do Sejmu Krajowego we Lwowie, 1911-1912 emeryt. Zmarł 13 XI 1912 r. we Lwowie. A. CzoŁowski, Ciuchciński Stanisław, [w:] Polski Słownik Biograficzny, t. IV, red. W. Konopczyński, Kraków 1938, s. 88-89; S. GrodZISKI, Sejm Krajowy Galicyjski 1861-1914, Kraków 2018, s. 403, 412.

${ }^{171}$ Gusztáv Károly von Majláth (1864-1940) - święcenia kapłańskie w 1887 r. w Ostrzyhomiu, 1897-1932 biskup ordynariusz diecezji Siedmiogród; propagował ideę zakładania katolickich stowarzyszeń społeczno-ekonomicznych, troszczył się o wychowanie i wykształcenie młodego pokolenia, wspierał rozwój szkolnictwa i prasy, po 1918 r. znalazł się wraz z diecezją w granicach Rumunii walcząc o prawa węgierskiej mniejszości do zachowania tożsamości narodowej, 1938-1940 emeryt w Budapeszcie, w 1938 r. Pius XI mianował go arcybiskupem tytularnym Soteropolis. Zmarł 18 III 1940 r. w Budapeszcie. Źródło: Majláth Gusztáv Károly - Wikipédiahu.wi kipedia.org〉wiki>Majláth_... [dostęp: 3 XI 2020]

172 Siedmiogród - kraina historyczna położona w centralnej Rumunii.

${ }^{173}$ Właściwie: Gyulafehérvár - węgierska nazwa miasta Alba Julia położonego w Siedmiogrodzie (Rumunia).

174 Temeszwar (węg.: Temesvár, rum. Timişoara) - miasto w zachodniej Rumunii, stolica rzymskokatolickiej diecezji.

175 János Csernoch (1852-1927) - Węgier, święcenia kapłańskie w 1874 r. w Ostrzyhomiu, dr teologii, studia specjalistyczne odbył w Rzymie w zakresie bibliotekarstwa, archiwistyki oraz prawa kanonicznego, w 1888 r. mianowany bibliotekarzem i archiwistą pałacu prymasów Węgier w Ostrzyhomiu, w 1900 r. został posłem do parlamentu w Budapeszcie, 1908-1913 biskup Csanád z siedzibą w Timișoarze, 1911-1913 arcybiskup metropolita kaloczański, 1913-1927 arcybiskup metropolita Ostrzyhomia, w 1914 r. kreowany kardynałem. Źródło: János Csernoch - Wikipedia, wolna encyklopedia, pl.wikipedia.org〉wiki>János_Csernoch [dostęp: 3 XI 2020].

${ }^{176}$ Augustin Fischer-Colbrie (1863-1925) - Węgier, święcenia kapłańskie w 1886 r. w Esztergom (Ostrzyhomiu) na Węgrzech, archiwariusz i sekretarz arcybiskupa, 1899-1901 prof. teologii dogmatycznej na Uniwersytecie Wiedeńskim, 1902-1904 rektor Pázmáneum (Collegium Pazmanianum) - instytutu kształcącego węgierskich duchownych w Wiedniu, znał 11 języków, 1904-1906 biskup pomocniczy diecezji Koszyce, 1906-1907 administrator tamże, 1907-1925 biskup 
czycach (Kassa), życzliwego Polakom - raczył poczynić potrzebne przygotowania w celu odznaczenia Ks. Biskupa Várady.

Co do pensji mojej zarządzono pewną zmianę w ministerstwie oświaty co do sposobu wypłacania. Dotychczas nie wiadomo mi, z jakiej przyczyny i czy zmiana ta będzie korzystną. Dlatego a także celem zapewnienia przyrzeczonej zapomogi z ministerstwa na kościół polski w Budapeszcie, z wdzięczności za otrzymane przysługi Ks. Biskupa Várady i dla zapewnienia życzliwości na przyszłość, odznaczenie będzie pożądane, co do osoby tegoż Ks. Biskupa V[árady].

$\mathrm{Z}$ najgłębszą czcią i poważaniem - oddany sługa

X Kelemen u[tca] 32

\section{Ks. Wincenty Danek}

3. 6.1910

\section{Dokument 19}

$\mathrm{Jego}^{\mathrm{s}}$ Ekscelencjo, Najprzewielebniejszy Księże Arcybiskupie!

Najserdeczniej dziękuję Jego Ekscelencji, Najprzewielebniejszemu Księdzu Arcybiskupowi, za list najłaskawszy. Dowodzi on, że Jego Ekscelencja, podobnie jakby Patron Kościoła Św. Józef nade mną czuwa.

Tutejszy Najprz[ewielebniejszy] Konsystorz ostatni kwit pensyjny zwrócił mi wraz z pismem stylizowanym na węgierski, z tym, że odtąd po myśli rozporządzenia węg[ierskiego] ministerstwa oświaty pensję moją mam pobierać półrocznie oraz że rozporządzenie to wydane zostało $\mathrm{w}$ związku z uregulowaniem kongruy ${ }^{177}$ wszystkich księży. Otóż, jeżeli to podwyższenie kongruy i mnie dotyczyć będzie, znośniejszą byłaby ta niewygoda półrocznego pobierania pensji. Dla braku czasu i nie chcąc się naprzykrzać, nie wypytywałem się nic więcej w tej sprawie, tym bardziej, że tylko do końca czerwca tym razem oczekiwać będę.

Intencji mszalnych mam 14, za przesyłkę nowych szczerze będę zobowiązany Jego Ekscelencji Najprzewielebniejszemu Księdzu Arcybiskupowi. Pani Hrabina Szapary wróciła z Włoch i gorliwiej zajmuje się sprawą zbierania funduszów. Zebraliśmy gotówki około 2000 koron. Na wiadomość, że Jego Ekscelencja przyrzekł ofiarować 1000 koron, $\mathrm{p}$ [ani] hrabina powiedziała: „to i ja na razie 1000 koron ofiaruję, ale nie gotówką". Gotówkę umieszczamy na węgierskim koncie czekowym poczt[owej] kasy oszczędności.

diecezjalny tamże, energiczny duszpasterz i organizator życia religijnego, po roku 1918 pozostał w Koszycach na terenie Czechosłowacji. Źródło: pl.wikipedia.org > wiki > Augustín_FischerColbrie - Wikipedia, wolna encyklopedia [dostęp: 2 XI 2020].

s Tekst pisany czarnym atramentem na 3 kartkach czystego papieru formatu in folio. W górnej partii karty tytułowej nota niebieską kredką ręką archiwisty: „Danek”. Obok nota czerwoną kredką ręką abp. J. Bilczewskiego: „Int[encji] 40”.

${ }^{177}$ Kongrua - najniższy ustawą określony dochód roczny kapłana. 
Pokornie proszę, aby Jego Ekscelencja, Najprzewielebniejszy Ksiądz Arcybiskup, był łaskaw w miarę uznania Swego skreślić parę słów polecających mnie do J[ego] Em[inencji] Ks. Kardynała Księcia Arcybiskupa Dra J[ohannesa] Katschthalera ${ }^{178}$ w Salzburgu ${ }^{179}$, aby tenże Ks. Kardynał - ufając mi na podstawie polecenia Jego Ekscelencji - przychylnie mógł załatwić tę prośbę, którą poprzez tut[ejszy] Najprz[ewielebniejszy] Konsystorz pragnę wnieść u władzy kościelnej w Salzburgu. Oto pragnę prosić, by w czasie Kongresu Mariańskiego wolno było w Kolegienkirche (jak ogłaszają programy) i w kościele katedralnym w Salzburgu zbierać składki na budowę kościoła pod wezwaniem Matki Bożej Nieustającej Pomocy w Budapeszcie, przy tym ogłoszeniu równocześnie, że składający ofiary nieco znaczniejsze (1-2 korony) mogą odebrać fascimilia własnoręcznego Apostol[skiego] Błogosławieństwa, jako pamiątkę ofiary. O tym ostatnim szczególe projektowanej kwesty nie byłbym zmuszonym wzmiankę uczynić w prośbie, którą wyślę do Najprz[ewielebniejszego] Konsystorza w Salzburgu, jednakże te fascimilia, które dałem tu zrobić pozwalają mieć nadzieję, że kwesta mogłaby się udać, chociażby w ograniczonej mierze.

Podobną kwestę pragnę przeprowadzić $\mathrm{w}$ czasie obchodu grunwaldzkiego ${ }^{180} \mathrm{~W}$ krakowskich kościołach za pośrednictwem tamtejszych księży. Do konsystorza Ks[iążęco]Bisk[upiego] w Krakowie wniosę także podobne podanie. O najłaskawsze polecenie tej sprawy Jego Ekscelencję, Najprzewielebniejszego Księdza Arcybiskupa, któremu sprawa zapewnienia potrzeb religijnych dla Polaków bawiących na obczyźnie nie jest obcą, uprzejmie a serdecznie proszę.

Mam też nadzieję, że pomimo trudnych początków sprawa kwesty i w innych stronach się uda, bo dopiero trawiliśmy czas na przygotowaniach akcji.

Prezes Głąbiński wstąpił do komitetu i polecił mi prosić księżną M[arię] Lubomirską ${ }^{181}$ w Wiedniu (Ringpark 6). Udział dra Barczy, burmistrza Budapesztu i ks[iężnej]

178 Johannes Baptist Katschthaler (1832-1914) - święcenia kapłańskie w 1855 r. w Salzburgu, 1855-1874 duszpasterz, wykładowca w Seminarium Duchownym i Uniwersytecie w Salzburgu, 1874-1880 prof. Uniwersytetu w Innsbrucku, w 1880-1900 kanonik Kapituły Katedralnej w Salzburgu, w 1882 r. mianowany rektorem miejscowego Seminarium Duchownego, 1891-1900 biskup pomocniczy archidiec. Salzburg, 1900-1914 arcybiskup metropolita tamże, w 1903 r. kreowany kardynałem. Źródło: Johannes Baptist Katschthaler - Wikipedia, wolna encyklopedia, pl.wikipedia. org〉wiki〉Johannes_Baptist_Katschthaler[dostęp: 5 XI 2020].

${ }^{179}$ Salzburg - miasto w Austrii położone w pobliżu granicy z Niemcami.

180 Obchody 500. rocznicy bitwy pod Grunwaldem miały miejsce w dniach 15-17 VII 1910 r. w Krakowie; pierwszego dnia tłumy zgromadziły się przy Pomniku Grunwaldzkim na placu Matejki, a 17 lipca na Błoniach kontynuowano celebrację. Na Mszę św. polową nie zgodził się kard. Jan Puzyna.

${ }^{181}$ Prawdopodobnie: Maria Lubomirska z Branickich (1873-1934) - księżna, córka Władysława Branickiego oraz Julii Potockiej, żona księcia Zdzisława Lubomirskiego - członka Rady Regencyjnej w Warszawie, matka trojga dzieci: Julii, Jerzego i Doroty; autorka wspomnień $P a-$ miętnik księżnej Marii Zdzisławowej Lubomirskiej 1914-1918, oprac. J. Pajewski, Poznań 2002; J. PAJewski, Lubomirski Zdzisław, [w:] Polski Stownik Biograficzny, t. XVIII, red. E. Rostworowski, Wrocław 1973, s. 68. 
Walerii Windischgrätz ${ }^{182} \mathrm{z}$ Sárospatak ${ }^{183}$ poprawił szansę powodzenia naszej sprawy. Poparcia nam tylko potrzeba, o które Jego Ekscelencję, Najprzewielebniejszego Księdza Arcybiskupa serdecznie proszę - łącząc wyrazy najgłębszej czci, poważania i wdzięczności, oddany sługa

X Kelemen u[tca] 32

Ks. W[incenty] Danek

10 czerwca 1910

\section{Dokument 20}

$J_{\text {Jego }}{ }^{t}$ Ekscelencjo, Najprzewielebniejszy Księże Arcybiskupie!

J[ego] E[kscelencja] minister Biliński przyrzekł mi napisać list do węgierskiego ministra skarbu z prośbą o zasiłek na budowę kościoła polskiego w Budapeszcie z funduszów loterii państwowej (dobroczynności) węgier[skiej]. Z uwagi, że minister Biliński i dalsze uczynił mi obietnice w tej sprawie, o których później ośmielę się szczegółowo zdać sprawozdanie Jego Ekscelencji proszę, aby Jego Ekscelencja, Najprzewielebniejszy Ksiądz Arcybiskup, raczył skreślić słów parę do ministra Bilińskiego, bawiącego w Ischlu ${ }^{184}$ - polecając dzieło to temuż zacnemu Polakowi. Eksc[elencja] Biliński okazał wielkie zainteresowanie w ogóle ideą polską, za co - odmiennie od uwłaczeń innych osób i dzienników - wszyscy jesteśmy mu wdzięczni.

Po wtóre upraszam, aby Jego Ekscelencja, Najprzewielebniejszy Ksiądz Arcybiskup, raczył w kurendzie konsystorskiej polecić dla parafii niemieckich i dla kolonii niemieckich w Galicji - wydawany dla ludzi w niemieckim języku: „Sankt Bonifatius” ${ }^{185}$ - na podobieństwo rozszerzanego w Galicji spod redakcji O. Mohla ${ }^{186}$ Tow[arzystwo] Jez[usowe] „W obronie Prawdy" 187 , to jest tak, jak to pisemko swego czasu było polecane w kurendzie.

182 Właściwie: Waleria Maria Dezsewffych Windisch-Grätz (1830-1912) - księżna węgierska, żona generalnego inspektora armii austriackiej gen. Ludwika Windisch-Grätza (1830-1903). Rodzina ta była ostatnim właścicielem dóbr Sárospatak do roku 1945.

${ }^{183}$ Sárospatak - miasto w północno-wschodnich Węgrzech.

${ }^{\mathrm{t}}$ Tekst pisany czarnym atramentem na 3 kartkach czystego papieru formatu in folio. W górnej partii karty tytułowej nota niebieską kredką ręką archiwisty: „Danek”.

${ }^{184}$ Ischl - miasto uzdrowiskowe w środkowej Austrii.

185 „Sankt Bonifatius. Apologetische Monatschrift” - katolicki periodyk wydawany w Wiedniu od $1904 \mathrm{r}$.

${ }^{186}$ Aleksander Mohl (1864-1913) - święcenia kapłańskie w 1891 r. w Zakonie oo. Jezuitów, 1893-1896 wykładowca j. francuskiego w Zakładzie Naukowo-Wychowawczym w Chyrowie, 1897-1898 wykładowca teologii dogmatycznej w Seminarium Duchownym w Jassach, 1898-1899 wykładowca prawa kanonicznego w zakonnym Seminarium Duchownym w Krakowie, 1899-1901 kaznodzieja w Cieszynie i Krakowie, 1901-1902 misjonarz w Afryce, 1906-1907 redaktor pisma „Głosy Katolickie”, 1907-1911 współtwórca i redaktor periodyku „W obronie Prawdy”, autor publikacji teologiczno-polemicznych. Mohl Aleksander, [w:] Encyklopedia wiedzy..., s. 434.

187 „W Obronie Prawdy” - czasopismo wydawane przez polskich oo. Jezuitów; jednym z założycieli oraz naczelnym redaktorem był w latach 1907-1911 o. Aleksander Mohl SJ. 
Proszę także uprzejmie, by Jego Ekscelencja, Najprzewielebniejszy Ksiądz Arcybiskup, polecił komu sporządzenie spisu niemieckich parafii w Galicji i na Bukowinie, i przekazanie tego spisu redakcji „Sankt Bonifatius”, drukowanego w Wiedniu u św. Norberta nakładem akcyjnego komitetu „Der Bonifatius Vereine Österreichs”, a redagowanego u oo. Benedyktynów w Pradze. W Wiedniu w tym towarzystwie św. Bonifacego uczyniono mnie nadzieję, że jeżeli „Bonifatius Blatt”188 (który jest wzorem dla pisma naszego „W Obronie Prawdy”) rozchodzić się będzie w Galicji i na Węgrzech, będę mógł otrzymać subwencję na kościół polski w Budapeszcie. To polecenie tego niemieckiego pisma we lwowskiej kurendzie byłoby jednym więcej dowodem, zaprzeczającym niegodną potwarz rzekomej polonizacji Niemców w Galicji przez duchowieństwo. Związek św. Bonifacego wspomaga dość znacznie budowę kościołów przede wszystkim w Wiedniu.

Co do Eks[celencji] Bilińskiego, na audiencji trafiłem na jakąś szczególnie szczęśliwą chwilę. Nazajutrz p[an] Biliński miał wyjeżdżać na urlop. Boję się, aby sprawa bez możnego poparcia - nie poszła w niepamięć. Dlatego Ekscelencję o interwencję łaskawą pokornie proszę.

Z najgłębszą czcią i poważaniem pozostaję wdzięcznym i oddanym donosząc, że sprawa kongruy mojej nie uległa zmianie. Na Węgrzech kongruę wszystkim księżom półrocznie rząd wypłaca. Mam w Bogu nadzieję, że to, co otrzymuję na utrzymanie mnie wystarczy.

Budapeszt, X Kelemen u[tca] 32

Ks. Wincenty Danek

30 lipca 1910

\section{Dokument 21}

\section{$\dagger$}

Jego ${ }^{u}$ Ekscelencjo, Najprzewielebniejszy Księże Arcybiskupie!

Eks[celencja] minister Biliński przyrzekł mi latem uprosić pana Drehera w czasie zebrań izby panów ${ }^{189}$ o grunt pod kościół polski w Budapeszcie. Różne okoliczności

Autor listu pomylił fakty. Otóż w „Kurendzie” lwowskiego Konsystorza Metropolitalnego przed rokiem 1910 nie anonsowano periodyku „W obronie Prawdy”, lecz publikację o. Aleksandra Galleraniego SJ W pogoni za prawda (Poznań 1907-1908), przełożoną z j. włoskiego na j. polski przez o. Mohla. Rekomendacja czasopisma „Święty Wojciech w obronie Prawdy” ukazała się na łamach „Kurendy” dopiero w 1911 r. [Recenzja i rekomendacja dzieła: A. GALLERANI, W pogoni za prawda, tłum. A. Mohl, Poznań 1907-1908], „Kurenda Konsystorza Metropolitalnego obrządku łacińskiego” 1909, nr 2, s. 17; Poleca się nowe ksiązki i wydawnictwa, „Kurenda Konsystorza Metropolitalnego obrządku łacińskiego" 1911, nr 4, s. 56.

${ }^{188}$ Właściwie: „Bonifatiusblatt” - periodyk dla katolików niemieckiego obszaru językowego ukazujący się od $1852 \mathrm{r}$.

u Tekst pisany czarnym atramentem na 2 kartkach czystego papieru formatu in folio. W górnej partii karty tytułowej nota niebieską kredką ręką archiwisty: „Danek”. 
skłaniają mnie, by spieszyć się w tej sprawie. Dzisiaj otrzymawszy wiadomość, że p[an] Dreher należy także w bież[ącym] roku do wspólnych delegacji, upraszam pokornie a usilnie, aby Jego Ekscelencja, Najprzewielebniejszy Ksiądz Arcybiskup, raczył łaskawie, o ile możności, jak najszybciej pomówić z polskimi członkami wspólnych delegacji w Sejmie Galicyjskim być może jeszcze obecnymi, w szczególności z p[anem] d[okto]rem Głąbińskim, który jest także członkiem naszego Komitetu budowy kościoła polskiego w Budapeszcie i wiele okazał nam życzliwości. O ile by Jego Ekscelencja nie mógł być także podówczas we Wiedniu, o co bardzo serdecznie ośmielam się prosić, obecną moją prośbę ograniczyłbym w ten sposób, by wyjednać u Jego Ekscelencji zachętę polskich członków delegacji ku temu, aby razem z min[istrem] Bilińskim formalnie otoczywszy kołem p[ana] Drehera w Sali zebrań nalegali, dopóki nie otrzymają przyrzeczenia darowizny. Darowizna ta z uwagi na ogromną drożyznę tutejszych gruntów (jest) byłaby tak znaczną, że niektórym osobom niewtajemniczonym wprawdzie w siłę agitacji nie chce się w możliwość jej wierzyć.

Donosząc, że od Sodalicji Mariańskiej Kapłanów Krakowskiej Diecezji otrzymaliśmy za pośrednictwem Najprz[ewielebniejszego] Ks. Biskupa Nowaka 1000 koron i przyrzeczenie znaczniejszej ofiary z krakowskiego konsystorza, jak również składając sprawozdanie, że obecny Ks. Arcybiskup [... $]^{\mathrm{v}}$.

Łączę wyrazy największej czci, poważania i wdzięczności z tym także przekonaniem, że starania Jego Ekscelencji w naszej sprawie - da Pan Bóg - uwieńczone pomyślnym skutkiem przyniosą prawdziwą pociechę Ojcowskiemu Jego Sercu w naszych troskach: J[ego] E[kscelencji] Najprzewielebniejszego Księdza Arcybiskupa oddany sługa

Budapeszt, X Kelemen u[ca] 32

Ks.Wincenty Danek

8 X 1910

\section{Dokument 22}

Jego ${ }^{w}$ Ekscelencjo, Najprzewielebniejszy Księże Arcybiskupie!

Upraszam uprzejmie, by Jego Ekscelencja, Najprzewielebniejszy Ksiądz Arcybiskup, jadąc na konferencję Ks. Biskupów do Wiednia - wstąpił do Koszyc ${ }^{190}$ dla załatwienia

${ }^{189}$ Izba Panów - wyższy organ Rady Państwa w Wiedniu 1861-1866, w latach 1867-1918 organ Rady Państwa dla krajów przedlitawskich Austro-Węgier. W jej skład wchodzili członkowie domu cesarskiego, przedstawiciele episkopatu katolickiego z tytułami książęcymi, reprezentanci arystokracji, wybitni politycy, duchowni, ludzie kultury. Tworzyli oni kilka kategorii: mianowani arcyksiążęta domu habsburskiego, wiryliści, członkowie dziedziczni i członkowie dożywotni. Izba Panów miała równorzędne kompetencje legislacyjne z Izbą Poselską.

${ }^{\mathrm{v}}$ Dwie linijki zamazane czarnym atramentem przez autora pisma.

${ }^{\mathrm{w}}$ Tekst pisany czarnym atramentem na 3,5 kartkach czystego papieru formatu in folio. W górnej partii karty tytułowej nota niebieską kredką ręką archiwisty: „Danek”.

${ }^{190}$ Koszyce - miasto na Słowacji. 
sprawy odznaczenia Ks. Biskupa Varady, szefa sekcji w (tut[ejszym]) węg[ierskim] ministerstwie oświaty, która to sprawa jest tu na Węgrzech sympatyczną. Proszę tedy, by Jego Ekscelencja prócz odwiedzenia dość licznej kolonii polskiej, której duchowym kierownictwem zajmuje się z własnej woli ks. Władysław Ziemliński ${ }^{191}$, ekskapucyn z przemyskiej diecezji mieszkający w Koszycach przy Kovács utca - jak mnie pisał raczył pomówić z życzliwym Polakom Ks. Biskupem Fischerem-Colbrie w Koszycach, który przyrzekł mnie ustnie poprzeć sprawę zbierania funduszów na kościół polski w Budapeszcie za pomocą kurendy konsystorskiej, chociaż na podanie pisemne nie otrzymałem odpowiedzi. Ks. Ziemliński rad by otrzymać płacę jaką od rządu węgierskiego, ale Ks. biskup Fischer-Colbrie jest podobno wobec rządu pod tym względem skrępowany.

Ponadto proszę, aby Jego Ekscelencja, Najprzewielebniejszy Ksiądz Arcybiskup, raczył na konferencjach Ks[ięży] Biskupów postawić wniosek polecający wszelkiego rodzaju kongregacjom Mariańskim i Sodalicjom, by pomagały tzw. Regisvereinom ${ }^{192}$ i Frauen für Sorge vereinom ${ }^{193}$ a) w wyszukiwaniu konkubinatów w wielkich miastach, b) w wyjednywaniu dokumentów potrzebnych do sanacji konkubinatów. Może przykład Wiednia podziała pod tym względem i na Węgry.

Wreszcie proszę, by Jego Ekscelencja raczył wglądnąć w sprawę należącego do lwowskiej diecezji, a we Wiedniu przebywającego ks. Łukaszkiewicza ${ }^{194}$, a to drogą informacji zaciągniętych u sióstr Nazaretanek (polskich) we Wiedniu i ks. dra Gerstmanna $^{195}$ (lub Ks[ięży] Zmartwychwstańców). Co do Koszyc proszę, by Jego Ekscelencja raczył tak zapowiedzieć Swój przyjazd, aby ks. Ziemliński mógł, najlepiej w niedzielę, ogłosić robotnikom ten zamiar i żądać by się zgromadzili, choćby powszedniego dnia późnym wieczorem. Jednakże około 13 listopada Ks. Biskup Fischer-Colbrie będzie

${ }^{191}$ Osoba niezidentyfikowana.

${ }^{192}$ Zniekształcony j. niem.: Regis-Verein - religijne stowarzyszenie funkcjonujące w dobie monarchii austro-węgierskiej.

${ }^{193}$ Zniekształcony j. niem.: Frauen für Sorge-Verein - społeczno-religijne stowarzyszenie funkcjonujące w dobie monarchii austro-węgierskiej.

${ }^{194}$ Julian Łukaszkiewicz (1857-1937) - święcenia kapłańskie w 1881 r. we Lwowie, 1881-1882 wikariusz par. Sasów, 1882-1883 wikariusz par. Chorostków, 1883-1884 wikariusz par. Skała, 1884-1937 urlop chorobowy, honorowy kapelan Bazyliki Loretańskiej, kawaler bułgarskiego Krzyża Świętych Cyryla i Metodego, odznaczony Krzyżem Czerwonym i Złotym. Zmarł w 1937 r. w Rzeszowie. Schematismus [...] 1882-1938, Leopoli 1882-1938, passim.

195 Adam Gerstmann (1873-1940) - lwowski duchowny rzymskokatolicki, dr teologii, katecheta gimnazjalny we Lwowie, 1900-1907 zastępca profesora teologii pastoralnej na Wydziale Teologicznym Uniwersytetu Lwowskiego, 1907-1920 profesor tej dyscypliny tamże, 1920-1940 profesor teologii moralnej szczegółowej tamże, w roku akad. 1927/28 i 1932/33 rektor uczelni, wielokrotny dziekan, 1923-1935 prezes Koła Księży Prefektów Archidiecezji Lwowskiej, ceniony pedagog i znawca problematyki szkolnictwa wyższego. J. WoŁCZAŃsKI, Wydział Teologiczny Uniwersytetu Jana Kazimierza we Lwowie 1918-1939, Kraków 2002, passim. 
zapewne na wiecu katolickim w Budapeszcie. Z Koszyc jest wprost linia kolej[owa] do Oderbergu ${ }^{196}$.

$\mathrm{Z}$ najgłębszą czcią i poważaniem - wdzięczny i oddany sługa

Chwilowo we Wiedniu - 26 X 1910

Ks. Wincenty Danek

\section{Dokument 23}

Jego ${ }^{x}$ Ekscelencjo, Najprzewielebniejszy Księże Arcybiskupie!

Pozwalając sobie Jego Ekscelencji, Najprzewielebniejszemu Księdzu Arcybiskupowi, złożyć korne życzenia świąteczne i noworoczne donoszę, że wobec energicznego zajęcia się sprawą budowy naszego kościoła i zainteresowania, jakie okazał burmistrz Budapesztu dr Stefan Barczy, sprawa ta poczyna wchodzić na pomyślniejsze tory.

Pan Barczy nakazał sporządzić plan naszego kościoła i oglądnąć się za miejskim gruntem odpowiednim na kościól, a właśnie Ks. Biskup Varady w ministerstwie oświaty od tych okoliczności uczynił zależnym znaczną (kilka dziesięciotysięczną) zapomogę rządową z funduszów, którymi rząd obecnie po zaciągnięciu znacznej pożyczki rozporządza. Wstyd mi jednak doprawdy, że na zapytania wszystkich, którzy by tu nam chcieli dopomóc, a ciekawych, ileśmy już w Galicji zebrali, nie mogę dać pocieszającej odpowiedzi ani takiej, która by do dalszej skutecznej życzliwości zachęcała.

Dlatego ośmielam się powtórzyć tu radę jednego starszego kapłana mi udzieloną z tym, abym uprosił Jego Ekscelencję, Najprzewielebniejszego Księdza Arcybiskupa, o napisanie noworocznego listu do J[ego] Em[inencji] Ks. Kardynała Klaudiusza Vaszary, w którym by Jego Ekscelencja, dziękując za dotychczasowe względy, raczył polecić sprawę naszą opiece Jego Eminencji, o co pokornie prosimy.

Sufragan Ks. Biskup Kohl przyrzekł mi nasze dzieło (co do zapomogi) w ewidencji, cóż kiedy, od siebie to dodaję, takich dzieł, w których wyczekuje się na hojność Ks. Kardynała jest bardzo wiele, a ja powtórzyć mogę wraz z chorymi nad sadzawką Siloe ${ }^{197}$ : „Hominem non habeo!”'198 Pomoc ta byłaby rzeczywiście moim uzdrowieniem. $\mathrm{Z}$ obawy, by mnie kto nie wyprzedził i dlatego także, bo miałbym więcej czasu na

${ }^{196}$ Oderberg - miasto na Śląsku Cieszyńskim w Czechach przy ujściu rzeki Olzy do Odry.

${ }^{\mathrm{x}}$ Tekst pisany czarnym atramentem na 3 kartkach czystego papieru formatu in folio. W górnej partii karty tytułowej nota niebieską kredką ręką archiwisty: „Danek”.

${ }^{197}$ Pomyłka autora, który połączył ze sobą dwa różne fragmenty Ewangelii. Nad sadzawką Siloe Chrystus uzdrowił człowieka niewidomego od urodzenia, polecając mu obmyć oczy wodą z tego zbiornika (J 9,1-8). Natomiast nad sadzawką Betesda (Owczą) spośród siedzących tam wielu chorych w oczekiwaniu na nadprzyrodzone poruszenie wody i wejście doń w celu odzyskania zdrowia, Chrystus uzdrowił człowieka chorego od 38 lat, któremu nikt nie pomógł w zanurzeniu się w wodzie. Na pytanie, czy chce zostać uzdrowiony, chory odparł: „Panie, nie mam człowieka, aby mnie wprowadził do sadzawki”. Otrzymał więc łaskę uzdrowienia (J 5,1-9).

${ }^{198}$ Łac.: nie mam człowieka. 
zajmowanie się może jeszcze ważniejszymi sprawami naszych robotników, jak jest troska o Dom Boży.

Tym pilniej śmiem polecić rzecz tę Jego Ekscelencji, Najprzewielebniejszemu Księdzu Arcybiskupowi, którego pozostaję wiernym sługą, strzegącym czci, poważania i wdzięczności należnej Jego Ekscelencji

X Kelemen u[tca] 32

\author{
Ks. Wincenty Danek
}

W Budapeszcie, 14 grudnia 1910

\title{
Dokument 24
}

$\mathrm{Jego}^{\mathrm{y}}$ Ekscelencjo, Najprzewielebniejszy Księże Arcybiskupie!

Za najłaskawszy list Jego Ekscelencji, Najprzewielebniejszego Księdza Arcybiskupa, serdeczne składam w pokorze dzięki. Powtarzam: słowa Arcypasterza są dla mnie jakby dżdżem i rosą dla pokarmu spragnionej rośliny.

Obecnie znów zbieg okoliczności zmusza mnie prosić Jego Ekscelencję, Najprzewielebniejszego Księdza Arcybiskupa, o łaskawe zlecenie przesłania mnie planu kościoła na 500-600 osób wraz z kosztorysem ${ }^{199}$ z Najprz[ewielebniejszego] Konsystorza. Ks. Biskup Varady bowiem w ministerstwie oświaty żąda ode mnie przedłożenia tego planu. Wprawdzie burmistrz dr Barczy kazał sporządzić plan na 800 osób, ale miasto zwyczajem swoim budując i projektując wszystko na wielką skalę zrobiło plan za drogi, którego Ks. Biskup Varady nie przyjął, polecając redukcję. Ta jednak tu jest utrudniona, po przedsięwziętych próbach o tym piszę, że łatwiej będzie przedłożyć jakikolwiek inny plan prowizorycznie $\mathrm{w}$ kosztorysie przetłumaczonym dodając ceny jednostkowe, tutejszym odpowiadające stosunkom. Rozumiem pod tą prośbą chęć wypożyczenia planu, jako substratu do ocenienia w ministerstwie, ile mamy otrzymać jako zapomogę.

Ośmielam się prosić Jego Ekscelencję, Najprzewielebniejszego Księdza Arcybiskupa, o możliwy pośpiech $\mathrm{w}$ tej sprawie, abyśmy mogli korzystać $\mathrm{z}$ funduszu zasilanego $\mathrm{z}$ interkalarnych dochodów ${ }^{200}$ wpływających $\mathrm{z}$ wakujących Biskupstw węgierskich.

y Tekst pisany czarnym atramentem na 2 kartkach czystego papieru formatu in folio. W górnej partii karty tytułowej nota niebieską kredką ręką archiwisty: „Danek”.

${ }^{199} \mathrm{~W}$ trosce o rozbudowę sieci kościołów i kaplic w archidiecezji lwowskiej ob. łac., a jednocześnie dbając o ich architekturę, abp Bilczewski zamówił u lwowskiego architekta Tadeusza Obmińskiego plany i kosztorysy na obiekty sakralne mogące pomieścić 200, 400 oraz 600 osób. Materiały te pozostawały w Konsystorzu Metropolitalnym we Lwowie do dyspozycji kapłanów podejmujących trud budowy świątyń. M. TARnAwsKi, Arcybiskup Józef Bilczewski. Krótki rys życia i prac, Lwów 1923, s. 51.

${ }^{200}$ Dochody za czas wakansu od opróżnienia beneficjum do objęcia go przez nowego beneficjata, po odliczeniu wszystkich wydatków. 
Ponawiając korne a serdeczne życzenia Wesołych Świąt i Szczęśliwego Nowego Roku pozostaję dla Jego Ekscelencji, Najprzewielebniejszego Księdza Arcybiskupa, oddanym sługą z czcią najwyższą i żywą wdzięcznością

X Kelemen u[tca] 32

Ks. W[incenty] Danek

22 grudnia 1910

\section{BIBLIOGRAFIA}

\section{Źródła rękopiśmienne}

Archiwum Archidiecezji Lwowskiej ob. łac. w Krakowie

bsygn., teczka: Korespondencja abp. Józefa Bilczewskiego. Listy ks. Wincentego Danka do tegoż z lat 1900-1919

bsygn. teczka: Korespondencja abp. Józefa Bilczewskiego, Dokumenty dotyczące budowy kościoła polskiego w Budapeszcie

bsygn., J. Bilczewski, Dziennik, Lwów 1900-1923

bsygn., teczka: Korespondencja abp. J. Bilczewskiego, Kopia pisma tegoż do ministra Ludwika Ćwiklińskiego, Lwów 29 III 1918 r.

Archiwum ks. Józefa Wołczańskiego w Krakowie

bsygn., Spis duchowieństwa i parafii archidiecezji w Lubaczowie 1981, Lubaczów 1981, mps

\section{Źródła drukowane}

BILCZEWSKI J., Chleb żywota. List pasterski do kapłanów i wiernych, Lwów 1910, 1911.

BILCZEWSKI J., List pasterski w pięćsetną rocznicę bł Jakuba Strepy, Lwów 1909.

BILCZEWSKI J., Odezwa do WW. Duchowieństwa archidiecezji w sprawie Bractwa Nauki Chrześcijańskiej i nauczania katechizmu, „Kurenda Konsystorza Metropolitalnego obrządku łacińskiego" 1912, nr 2, s. 9-12.

BILCZEWSKI J., Życie święte, święta śmierć. List pasterski do kapłanów i wiernych, Lwów 1910.

Kościół rzymskokatolicki i Polacy w Małopolsce Wschodniej podczas wojny ukraińsko-polskiej 1918-1919. Źródła, t. I-II, oprac. J. Wołczański, Lwów-Kraków: Wydawnictwo Bł. Jakuba Strzemię Archidiecezji Lwowskiej 2012.

„Nic dla siebie, wszystko dla Boga i bliźniego”. Święty arcybiskup Józef Bilczewski we wspomnieniach, oprac. J. Wołczański, Lwów-Kraków: Wydawnictwo Bł. Jakuba Strzemię Archidiecezji Lwowskiej 2016.

[Nota w sprawie finansowego wsparcia budowy kościoła polskiego w Budapeszcie], „Kurenda Konsystorza Metropolitalnego obrządku łacińskiego" 1911, nr 6, s. 71-72.

Poleca się nowe książki i wydawnictwa, „Kurenda Konsystorza Metropolitalnego obrządku łacińskiego" 1911, nr 4, s. 56.

[PUChalsKi W.], Podręcznik adoracji Najświętszego Sakramentu ułożony z polecenia Najprzew[ielebniejszego] Arcybiskupa Metropolity Lwowskiego, Lwów 1902. 
[Recenzja i rekomendacja dzieła: A. Gallerani, W pogoni za Prawdą, tłum. A. Mohl (Poznań 1907-1908)], „Kurenda Konsystorza Metropolitalnego obrządku łacińskiego” 1909, nr 2, s. 17.

Regulamin Bractwa Nauki Chrześcijańskiej, „Kurenda Konsystorza Metropolitalnego obrządku łacińskiego" 1912, nr 2, s. 14-17.

Schematismus (Catalogus) universi venerabilis cleri saecularis et regularis archidioecesis Leopoliensis rit[us] lat[ini] 1876-1939, Leopoli 1876-1939.

Statuta Bractwa Nauki Chrześcijańskiej w archidiecezji lwowskiej obrz[ądku] lac[ińskiego], „Kurenda Konsystorza Metropolitalnego obrządku łacińskiego" 1912, nr 2, s. 12-14.

WoŁCZAŃSKI J., Eksterminacja narodu polskiego i Kościoła rzymskokatolickiego przez ukraińskich nacjonalistów w Małopolsce Wschodniej w latach 1939-1945. Materiały źródłowe, cz. 1, Kraków-Lwów: Wydawnictwo Bł. Jakuba Strzemię Archidiecezji Lwowskiej 2005.

\section{Opracowania}

BednAREK A., Kantak Kamil, [w:] Encyklopedia Katolicka, t. VIII, red. zbior., Lublin: TN KUL 2000, kol. 623-624 (biogram niepełny).

Bibliografia katolickich czasopism religijnych w Polsce 1918-1944, oprac. i red. Z. Zieliński, Lublin: TN KUL 1981.

Biliński Leon, [w:] Kto był kim w Drugiej Rzeczypospolitej, red. J. Majchrowski, Warszawa: BGW 1994, s. 32.

BuszKo J., Jaworski Władysław Leopold, [w:] Polski Słownik Biograficzny, t. XI, red. zbior., Wrocław-Warszawa-Kraków: Ossolineum, PAN 1964, s. 115-118.

Buszko J., Korytowski Witold, [w:] Polski Słownik Biograficzny, t. XIV, red. zbior., WrocławWarszawa-Kraków: Zakład Narodowy im. Ossolińskich, Wydawnictwo PAN 1968, s. 155157.

CzoŁowski A., Ciuchciński Stanisław, [w:] Polski Słownik Biograficzny, t. IV, red. W. Konopczyński, Kraków: Ossolineum 1938, s. 88-89.

DANEK W., Organizacje katolickie na Węgrzech, Warszawa 1920.

DANEK W., Robotnicy polscy w Budapeszcie, „Gazeta Podhalańska” 1913, nr 1, s. 9-10.

Der Bonifatius-Verein. Seine Geschichte, seine Arbeit und sein Arbeitsfeld 1849-1899, Paderborn 1899.

DęBowsKa M., Akcja społeczna w archidiecezji lwowskiej za rządów arcybiskupa Józefa Bilczewskiego (1901-1923), „Archiwa, Biblioteki i Muzea Kościelne” 1992, t. 61, s. 227-374.

Dunin-Borkowski J.S., Austriaccy radcy tajni w Galicji, Lwów 1901.

ENGelberT K., Kopp Georg, [w:] Lexikon für Theologie und Kirche, Bd. VI, herausg. von J. Höfer, K. Rahner, Freiburg im Br. 1961, kol. 537-538.

Galos A., Głąbiński Stanisław, [w:] Polski Słownik Biograficzny, t. VIII, red. zbior., WrocławKraków-Warszawa: Zakład Narodowy im. Ossolińskich, Wydawnictwo PAN 1959, s. 102-105.

GolemsKa A., Szyszko-Bohusz Adolf, [w:] Encyklopedia Katolicka, t. XIX, red. zbior., Lublin: TN KUL 2013, kol. 238-239.

GoŁęBIOwsKi J., Głąbiński Stanisław, [w:] Kto był kim w Drugiej Rzeczypospolitej, red. J. Majchrowski, Warszawa: BGW 1994, s. 39.

GrodZISKi S., Sejm Krajowy Galicyjski 1861-1914, Kraków: Księgarnia Akademicka 2018. 
GRUDZIŃSKI K., Tatka Marek Szczepan, [w:] Słownik polskich pisarzy franciszkańskich, red. H.E. Wyczawski, Warszawa: Archiwum Prowincji oo. Bernardynów 1981, s. 492.

JACHOWSKI J., Kantak Kamil, [w:] Wielkopolski słownik biograficzny, red. A. Gąsiorowski, J. Topolski, Warszawa-Poznań: PWN 1981, s. 313.

JózEFowiCz M., Kościół polski w Budapeszcie „małym Rapperswil”, „Archiwa, Biblioteki i Muzea Kościelne" 1996, t. 65, s. 427-441.

KALCZYŃSKa M., Napieralski Adam, [w:] Słownik biograficzny katolicyzmu społecznego w Polsce, t. II, red. zbior., Lublin: TN KUL 1994, s. 147-148.

Kardynał Adam Stefan Sapieha. Książę niezłomny, red. J. Urban, Kraków: PAU 2014, passim.

Kryża L., Powstanie i rozwój parafii, [w:] Kościół i Dom Polski w Budapeszcie, red. L. Kryża, M. Soboltyńska, [bmr], s. 3-33.

Księga Sapieżyńska, red. J. Wolny, t. I-II, Kraków: Polskie Towarzystwo Teologiczne 1982-1986.

KUFEL R.R., Słownik biograficzny księży pracujących w Kościele gorzowskim 1945-1956, t. IV, Zielona Góra: Wydawnictwo PDN 2019, s. 66-67.

KumOR B., Likowski Edward, [w:] Słownik polskich teologów katolickich, t. II, red. H.E. Wyczawski, Warszawa: ATK 1982, s. 525-527.

LeCHICKI C., Lubecki Kazimierz Adam, [w:] Polski Słownik Biograficzny, t. XVII, red. E. Rostworowski, Wrocław: Zakład Narodowy im. Ossolińskich, Wydawnictwo PAN 1972, s. 580-581.

MAndziuK J., Postacie Kościoła katolickiego na Śląsku, Warszawa: Adam 2016.

Mieloch Ignacy Marcin, [w:] Encyklopedia wiedzy o jezuitach na ziemiach Polski i Litwy 15641995, oprac. L. Grzebień, Kraków: WAM 1996, s. 421.

Mohl Aleksander, [w:] Encyklopedia wiedzy o jezuitach na ziemiach Polski i Litwy 1564-1995, oprac. L. Grzebień, Kraków: WAM 1996, s. 434.

Nitecki P., Biskupi Kościoła w Polsce. Słownik biograficzny, Warszawa: PAX 1992.

PAJEwski J., Lubomirski Zdzisław, [w:] Polski Słownik Biograficzny, t. XVIII, red. E. Rostworowski, Wrocław: Zakład Narodowy im. Ossolińskich, Wydawnictwo PAN 1973, s. 68.

Pamiętnik księżnej Marii Zdzisławowej Lubomirskiej 1914-1918, oprac. J. Pajewski, Poznań: Wydawnictwo Poznańskie 2002.

PATER J., Z dziejów wrocławskiego Kościoła, Wrocław: Muzeum Archidiecezjalne 1997.

Polskie czasopisma religijno-społeczne w XIX wieku. Materiały do katalogu, pr. zbior., Warszawa-Lublin: RW KUL 1988.

POPŁAwSKI Z., Dzieje Politechniki Lwowskiej 1844-1945, Wrocław-Warszawa-Kraków: Ossolineum 1992.

RaChwaŁ S., Ks. biskup dr Władysław Bandurski. Wzór kapłana-Polaka, Lwów 1913.

SAPIEŻYNA Z Windisch-GrAETZów M., My i nasze Siedliska, Kraków: Wydawnictwo Literackie 2003.

Sodalicja Mariańska, [w:] Encyklopedia wiedzy o jezuitach na ziemiach Polski i Litwy 15641995, oprac. L. Grzebień, Kraków: WAM 1996, s. 629-630.

Sopuch Stanisław, [w:] Encyklopedia wiedzy o jezuitach na ziemiach Polski i Litwy 1564-1995, oprac. L. Grzebień, Kraków: WAM 1996, s. 633.

StarzyŃski S., Abrahamowicz Dawid, [w:] Polski Słownik Biograficzny, t. I, red. W. Konopczyński, Kraków: PAU, Wydawnictwo Zakładu Narodowego im. Ossolińskich 1935, s. 9-10. 
STARZYŃSKi S., Badeni Stanisław Marcin, [w:] Polski Słownik Biograficzny, t. I, red. zbior., Kraków: PAU, Wydawnictwo Zakładu Narodowego im. Ossolińskich 1935, s. 209-211.

Szuster G., Wincenty Danek (1907-1976). Biografia nauczyciela, Kraków: Avalon 2017.

Szydłowski Antoni, [w:] Encyklopedia wiedzy o jezuitach na ziemiach Polski i Litwy 1564-1995, oprac. L. Grzebień, Kraków: WAM 1996, s. 670.

Święty Józef Sebastian Pelczar (1842-1924). Rektor Uniwersytetu Jagiellońskiego i biskup przemyski, [t. XVII], red. A. Kubiś, J. Wołczański, Kraków: Wydawnictwo Naukowe PAT 2005.

TARnAwSKi M., Arcybiskup Józef Bilczewski, Krótki rys życia i prac, Lwów 1923.

TARnowska M., Wspomnienia, Warszawa: Krajowa Agencja Wydawnicza 2002.

Turowski K., Micewski B., Thullie Maksymilian Marceli, [w:] Słownik biograficzny katolicyzmu społecznego w Polsce, t. III, red. zbior., Lublin: TN KUL 1995, s. 136-137.

WieliczKo M., Ksiądz Wincenty Danek (1870-1945), „Studia Polonijne” 17 (1996), s. 171-184.

WoŁcZAŃski J., Adam Stefan Sapieha w korespondencji z biskupami Galicji (Małopolski), [w:] Kardynał Adam Stefan Sapieha. Środowisko rodzinne, życie i dzieło, red. S. Stepień, Przemyśl: Południowo-Wschodni Instytut Naukowy 1995, s. 93-141.

WoŁCZAŃSKi J., Biogram i bibliografia prac drukowanych błogosławionego Józefa Bilczewskiego za lata 1888-1929, [w:] Błogosławiony Józef Bilczewski arcybiskup metropolita lwowski obrządku łacińskiego. Sesja naukowa na Uniwersytecie Jagiellońskim, Kraków 4-5 czerwca 2002, red. J. Wołczański, Kraków: Wydawnictwo Naukowe Papieskiej Akademii Teologicznej w Krakowie 2003, s. 17-47.

WoŁcZAŃSKI J., Wydział Teologiczny Uniwersytetu Jana Kazimierza we Lwowie 1918-1939, Kraków: Wydawnictwo Bł. Jakuba Strzemię Archidiecezji Lwowskiej 2002.

WyCZAwSKI H.E., Kantak Kamil Juliusz, [w:] Słownik polskich teologów katolickich, t. VI, red. L. Grzebień, Warszawa: ATK 1983, s. 30-41.

Wyczawski H.E., Pelczar Józef Sebastian, [w:] Słownik polskich teologów katolickich, t. III, red. H. E. Wyczawski, Warszawa: ATK 1982, s. 335-346.

Wysocki W.J., ŻAK A.C., Biskup Władysław Bandurski, Pruszków: „Ajaks” 1997.

ZDRADA J., Kozłowski Włodzimierz, [w:] Polski Słownik Biograficzny, t. XV, red. zbior., Wrocław -Warszawa-Kraków: Zakład Narodowy im. Ossolińskich, Wydawnictwo PAN 1970, s. 39-40.

ZIELIŃSKA T., Poczet polskich rodów arystokratycznych, Warszawa: WSiP 1997.

Żukowski P.M., Profesorowie Wydziału Prawa Uniwersytetu Jagiellońskiego, t. II: 1780-2012, Kraków: Wydawnictwo UJ 2014, s. 311-312.

\section{Netografia}

Zalążki i rozkwit ruchu polonijnego, www.bem.hu > Historia, - Bem Egyesület [dostęp: 2 XI 2020].

Księżniczka Maria Karolina Burbon-Burbon (1856-1941) ...pl.qaz.wiki`wiki, Princess_Maria_ Carolina_of_Bourbon [dostęp: 2 XI 2020].

Maria Szapáry - Historical records and family trees - MyHeritage [dostęp: 2 XI 2020].

Archidiecezja kalocsko-kecskemétska - Roman Catholic ...pl.qaz.wiki`wiki> Roman_Catholic _Archdiocese_of [dostęp: 3 XI 2020].

Year 1919, Necrology [Catholic-Hierarchy], www.catholic-hierarchy.org/events/n1919.html [dostęp: 15 XI 2020]. 
Bishop Jozsef Medard Kohl [Catholic-Hierarchy], www.catholic-hierarchy.org/bishop/bkohl.html [dostęp: 12 XI 2020].

Kolos Ferenc Vaszary - Wikipedia, wolna encyklopedia pl.wikipedia.org〉wiki> Kolos_Ferenc _Vaszary [dostęp: 3 XI 2020].

Mihály Károlyi - Wikipedia, wolna encyklopedia, pl.wikipedia.org`wiki〉 Mihály_Károlyi [dostęp: 3 XI 2020].

János Zichy, hr. Zisci : Myśl Konserwatywna, myslkonserwatywna.pl〉 janos-zichy-hr-zisc [dostęp: 3 XI 2020].

Majláth Gusztáv Károly - Wikipédia hu.wikipedia.org`wiki〉 Majláth_.... [dostęp: 3 XI 2020].

János Csernoch - Wikipedia, wolna encyklopedia, pl.wikipedia.org〉wiki〉 János_Csernoc [dostęp: 3 XI 2020].

Augustín_Fischer-Colbrie pl.wikipedia.org)wiki〉 - Wikipedia, wolna encyklopedia [dostęp: 2 XI 2020].

Johannes Baptist Katschthaler - Wikipedia, wolna encyklopedia, pl.wikipedia.org`wiki〉 Johannes _Baptist_Katschthaler [dostęp: 5 XI 2020].

Lajos Balás - Wikidata, www.wikidata.org〉wiki [dostęp: 8 XI 2020].

Wolfgang Radnai - Wikipedia, wolna encyklopedia, pl.wikipedia.org`wiki〉 Wolfgang_Radnai [dostęp: 8 XI 2020].

Bishop Lajos Rajner [Catholic-Hierarchy], www.catholic-hierarchy.org/bishop/brajner.html [dostęp: 24 XI 2020].

Zyta Burbon-Parmeńska - Wikipedia, wolna encyklopedia, pl.wikipedia.org`wiki〉Zyta_BurbonParmeńska [dostęp: 16 XI 2020].

Wilhelm II Hohenzollern - Wikipedia, wolna encyklopedia, pl.wikipedia.org`wiki〉 Wilhelm_II Hohenzollern [dostęp: 16 XI 2020].

Anton Dreher - Wikipedia, en.wikipedia.org〉wiki> Anton_Dr [dostęp: 16 XI 2020].

\title{
Relacje
}

Informacja ustna ks. dr. Marcina Kapłona, Przemyśl 14 XI 2020 r.

Informacja pisemna ks. Macieja Gawlika CR, Kraków 5 XI 2020 r.

Informacja pisemna br. Efrema Michalskiego OSB, Tyniec 18 XI $2020 \mathrm{r}$.

Informacje własne autora.

\author{
LISTY KS. WINCENTEGO DANKA \\ DO ABP. JÓZEFA BILCZEWSKIEGO Z LAT 1900-1919 \\ (CZĘŚĆ I) \\ Streszczenie
}

Niniejsza edycja źródeł historycznych dotyczy listów duchownego archidiecezji lwowskiej obrządku łacińskiego ks. Wincentego Danka (1870-1945) do metropolity lwowskiego abp. Józefa Bilczewskiego (1860-1923). Dokumenty te odnoszą się do lat 1900-1919, a więc niemal całego pontyfikatu lwowskiego hierarchy. Przechowywane są w spuściźnie po metropolicie w Archiwum Archidiecezji Lwowskiej ob. łac. w Krakowie. Nie zachowały się jednak listy abp. Bilczewskiego 
do ks. Danka. Tym bardziej cenne są te, które stanowią przedmiot niniejszej edycji choćby z tej racji, że nigdy dotąd nie były wykorzystywane w badaniach naukowych. Dodatkowym ich atutem jest zawarta w nich problematyka zabiegów polonijnego duszpasterza w Budapeszcie ks. Danka o zorganizowanie systematycznego duszpasterstwa dla rodaków, a nade wszystko starania o budowę kościoła. Inicjator tej akcji, za aprobatą tak kościelnych i państwowych czynników węgierskich, jak również abp. Bilczewskiego podjął szeroko zakrojoną akcję gromadzenia funduszy i poparcia w środowisku węgierskim i galicyjskim. Nawiązał kontakty z rodami arystokracji węgierskiej spokrewnionej ze sferami polskiego ziemiaństwa, pozyskał względy osób powiązanych z dworem cesarskim w Wiedniu, zdobył zaufanie niektórych członków rządu i parlamentu Austro-Węgier, co miało zaowocować zabezpieczeniem bazy materialnej planowanej inwestycji. Realizacji tak szczytnej idei przeszkodził wybuch I wojny światowej, wskutek czego finalizacja budowy kościoła pw. Najświętszej Maryi Panny Wspomożenia Wiernych doszła do skutku dopiero w 1926 r. Dokonano wówczas poświęcenia świątyni, a jej konsekracja miała miejsce cztery lata później.

Słowa kluczowe: abp Józef Bilczewski; ks. Wincenty Danek; archidiecezja lwowska obrządku łacińskiego; kościół pw. Najświętszej Maryi Panny Wspomożenia Wiernych w Budapeszcie; duszpasterstwo polonijne na Węgrzech; budowa świątyni dla Polaków

\author{
LETTERS OF THE REV. WINCENTY DANEK \\ TO ARCHBISHOP JÓZEF BILCZEWSKI FROM THE YEARS 1900-1919 \\ (PART I)
}

Summary

This edition of historical sources covers the letters of a clergyman of the Roman Catholic archdiocese of Lviv, the Rev. Wincenty Danek (1870-1945), to Archbishop of Lviv Józef Bilczewski (1860-1923). The documents span the years 1900-1919, i.e. almost the entire pontificate of the Lviv bishop. They are kept along with other archbishop's memorabilia in the Archives of the Lviv Archdiocese in Kraków. However, the letters of Archbishop Bilczewski to the Rev. Danek have not survived. That makes the ones covered in this edition even more valuable, given than they have never undergone scientific research before. Their additional benefit is the subjects discussed. They report the Rev. Danek's attempts to organise a permanent pastoral care for his compatriots in Budapest, and above all, to build a church. With the approval of both Hungarian ecclesiastical and state authorities, as well as of Archbishop Bilczewski, the reverend undertook a large-scale fund-raising and support campaign across the Hungarian and Galician communities. He established contacts with the Hungarian aristocracy related to the Polish landowners; he enlisted aid from the imperial court in Vienna; he won the trust of some members of the AustroHungarian government and parliament, which helped secure funds for the planned investment project. Its implementation was interrupted by the outbreak of the Great War, which is why the Church of Our Lady of Succour to the Faithful was not completed until 1926. The consecration of the temple followed four years later.

Keywords: Archbishop Józef Bilczewski; Rev. Wincenty Danek; Roman Catholic Archdiocese of Lviv; Church of Our Lady of Succour to the Faithful; Polish community pastoral care in Hungary; construction of a temple for Poles 